\title{
Applications and Potential of Genome-Editing Systems in Rice Improvement: Current and Future Perspectives
}

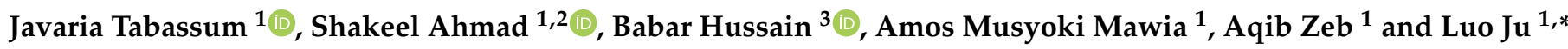 \\ 1 State Key Laboratory of Rice Biology, China National Rice Research Institute, Hangzhou 310006, China; \\ javaria.tabassum@outlook.com (J.T.); shakeelpbg@gmail.com (S.A.); amosyokis@gmail.com (A.M.M.); \\ aqibzeb@yahoo.com (A.Z.) \\ 2 Maize Research Station, Ayub Agricultural Research Institute, Faisalabad 38000, Pakistan \\ 3 Department of Biological Sciences, Middle East Technical University, 06800 Ankara, Turkey; \\ bhussain@sabanciuniv.edu \\ * Correspondence: luojurice@126.com or luoju01@caas.cn; Tel.: +86-135-7570-6965
}

Citation: Tabassum, J.; Ahmad, S.; Hussain, B.; Mawia, A.M.; Zeb, A.; Ju, L. Applications and Potential of Genome-Editing Systems in Rice Improvement: Current and Future Perspectives. Agronomy 2021, 11, 1359. https: / /doi.org/10.3390/ agronomy11071359

Academic Editors: V. Mohan Murali Achary and Malireddy K. Reddy

Received: 3 June 2021

Accepted: 29 June 2021

Published: 2 July 2021

Publisher's Note: MDPI stays neutral with regard to jurisdictional claims in published maps and institutional affiliations.

Copyright: (c) 2021 by the authors. Licensee MDPI, Basel, Switzerland. This article is an open access article distributed under the terms and conditions of the Creative Commons Attribution (CC BY) license (https:// creativecommons.org/licenses/by/ $4.0 /)$

\begin{abstract}
Food crop production and quality are two major attributes that ensure food security. Rice is one of the major sources of food that feeds half of the world's population. Therefore, to feed about 10 billion people by 2050, there is a need to develop high-yielding grain quality of rice varieties, with greater pace. Although conventional and mutation breeding techniques have played a significant role in the development of desired varieties in the past, due to certain limitations, these techniques cannot fulfill the high demands for food in the present era. However, rice production and grain quality can be improved by employing new breeding techniques, such as genome editing tools (GETs), with high efficiency. These tools, including clustered, regularly interspaced short palindromic repeats (CRISPR) systems, have revolutionized rice breeding. The protocol of CRISPR/Cas9 systems technology, and its variants, are the most reliable and efficient, and have been established in rice crops. New GETs, such as CRISPR/Cas12, and base editors, have also been applied to rice to improve it. Recombinases and prime editing tools have the potential to make edits more precisely and efficiently. Briefly, in this review, we discuss advancements made in CRISPR systems, base and prime editors, and their applications, to improve rice grain yield, abiotic stress tolerance, grain quality, disease and herbicide resistance, in addition to the regulatory aspects and risks associated with genetically modified rice plants. We also focus on the limitations and future prospects of GETs to improve rice grain quality.
\end{abstract}

Keywords: rice; grain yield; abiotic stress; biotic stress; grain quality; food security; CRISPR/Cas systems; base editing; prime editing

\section{Introduction}

Rice (Oryza sativa L.) is grown across the globe and consumed by approximately 3 billion people or around $50 \%$ of the world population [1,2]. Rice was grown on 162 million hectares and its global production was 755 million tons in 2019 (http:/ /www.fao.org/ faostat/en, accessed on 29 June 2021). The world population may rise anywhere from 9.7 to 11 billion in 2050 (https:/ / population.un.org/wpp/, accessed on 29 June 2021); thus, a significant increase in rice yield will be required to feed the growing population. The global demand for rice is estimated to increase by $50 \%$ by 2050 [3]. However, climate change is a major limiting factor for crop production and increases in temperature are leading to more frequent and severe drought spells and soil salinization [4]. Rice faces several biotic and abiotic stresses that significantly lower its production. Approximately $3000 \mathrm{~L}$ of water is needed to produce $1 \mathrm{~kg}$ of rice, while it is a drought susceptible species due to the thin cuticle wax and small root systems, drought can cause up to $100 \%$ yield losses [5]. Similarly, soil salinity could reduce $50 \%$ of global rice production [6] and cold stress also threatens rice production and quality [1]. Therefore, an increase in rice production and improvement of its grain quality are essential for healthy and sustainable life in the future [2]. An increase in 
rice yield and development of stress resilient rice plants are essential for global food security. Moreover, the improvement in grain quality parameters enhances consumer demand and commercial value of rice varieties [7]. Earlier, rice grain quality, climate resilience, disease resistance, and yield have improved via conventional breeding approaches (mutagenesis and hybridization). However, these techniques are time-consuming, tedious, require large mutant screens, and are prone to human biases [4]. Therefore, more powerful, precise, fast, and robust crop improvement approaches, such as genome editing, will be required to meet the rice demand by the ever-growing world population (Figure 1).

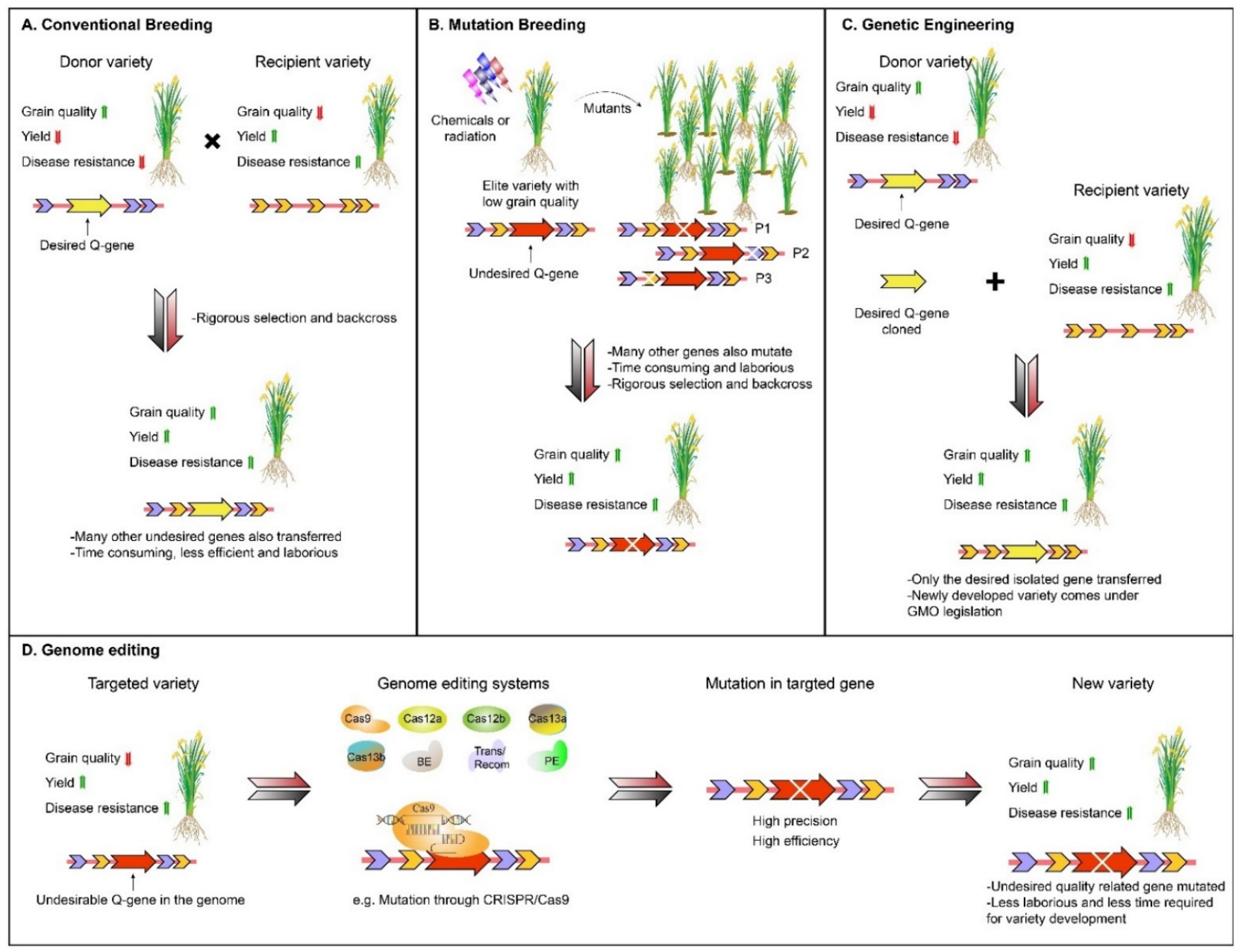

Figure 1. Overview of plant breeding approaches for developing rice varieties with improved yield, stress tolerance and grain quality. (A) Conventional breeding for crop improvement, e.g., rice grain quality improvement. (B) Mutational breeding approach for rice grain quality improvement. (C) Genetic engineering for incorporating the desired gene in popular rice variety. (D) Application of gene editing tools for rice plant improvement, e.g., targeting rice grain quality sensitive genes via CRISPR/Cas systems. Upward green arrow shows improved or high grain quality/yield/disease resistance in the plant. Downward red arrow shows deprived or low grain quality/yield/disease resistance in the plant. Q-gene, Quality gene; Cas9, CRISPR-associated protein 9; Cas12a, CRISPR-associated protein 12a; Cas12b, CRISPR-associated protein 12b; Cas13a, CRISPR-associated protein 13a; Cas13b, CRISPR-associated protein 13b; BE, Base Editors; Trans/Recom, Transposases or Recombinases; PE, Prime Editors. 
Conventional breeding and mutagenesis techniques drag undesirable genes along with the targeted genes, and take a long time; henceforth, they do not fit the requirements (i.e., of rapidly increasing the production and quality parameters to cope with world hunger and malnutrition challenges). Additionally, hybridization is possible between two plants of the same species, limiting the introduction of new genes and traits. Powerful genome editing technologies (GETs) tackle these limitations of conventional mutational breeding and are capable of transferring a desired trait in any plant species in a short time (Figure 1) and, thus, have great potential for speeding up the breeding programs. However, detailed information about the gene sequence, structure, gene function, novel genes and quantitative trait loci (QTL) responsible for traits of interest is vital for application of GETs [8]. GETs modify a specific gene of the desired trait by cutting DNA via target-specific nucleases; thus, the breeding processes are swift. Site-specific endonucleases (SSE), i.e., zinc finger nucleases, transcription activator-like effector nucleases [9], have been introduced in the last decade and are widely used as gene-editing tools.

Recent advancements in GETs involve the development of a clustered, regularly interspaced short palindromic repeats (CRISPR)/CRISPR-associated protein (Cas) system. There are multiple Cas proteins, such as Cas8, Cas9, Cas12a, or Cpf1 (CRISPR from Prevotella and Francisella1); variants including F. novicida U112 (FnCpf1) and Lachnospiraceae bacterium ND2006 LbCpf1); Cas12b, Cas13a, Cas13b, modified forms, i.e., catalytically dead or endonuclease deficient Cas9 (dCas9), nickase Cas9 (nCas9); and orthologues of Cas9, such as Streptococcus pyogenes Cas9 (SpCas9), Staphylococcus aureus Cas9 (SaCas9), Streptococcus thermophilus Cas9 (StCas9), Neisseria meningitides Ca9 (NmCas9), Campylobacter jejuni Cas9 (CjCas9), etc. [10,11]. They have been used for genome editing through CRISPR technology to improve multiple traits in plants. Among these, the CRISPR/Cas9 system is the most adopted, easier, promising, reliable, and efficient one used for improving yield, stress resilience, herbicide resistance, and end-use quality in several models and crop plants, such as Arabidopsis thaliana, Nicotiana benthamiana, Physcomitrella patens, Camelina sativa, barley, corn/maize, citrus, cucumber, soybean, tobacco, tomato, wheat, and rice [12]. Recently, CRISPR-Cas12a and CRISPR-Cas13 systems, which target DNA and RNA, respectively, have been introduced to overcome the limitations of Cas9, owing to their reliability $[13,14]$. Furthermore, a new technique named base editing (BE), aiming to improve editing technologies by enhancing their proficiency and accuracy, has been introduced and being applied in plant biology [15-18]. In addition, recombinases and the discovery of prime editing (PE) technology are also used to improve the competence of the genome editing system [19-23]. A detailed comparison of pre-CRISPR GETs, different Cas protein orthologues, prime, and BE technologies have been illustrated in Figure 2. Keeping in view with the rapid development in the field of genome editing in general and CRISPR technologies in particular, we discuss the advancements made in CRISPR/Cas9, modified Cas proteins, base and prime editing systems, with the passage of time, and their applications, to improve rice grain yield, tolerance to abiotic stresses, disease resistance, herbicide resistance, and end-use quality. Due to the direct consumption of rice grain by human beings, the ethics and regulatory aspects of genetically modified rice plants via GETs are discussed. We also focus on the limitations and future prospects of GETs to improve rice for the above-mentioned traits. 


\begin{tabular}{|c|c|c|c|c|c|c|c|c|c|}
\hline System name & Illustration & Evolution & Components & $\begin{array}{l}\text { Typef } \\
\text { class }\end{array}$ & Target & Target window & Edit type & $\begin{array}{l}\text { Reagents(s), } \\
\text { Method(s) }\end{array}$ & Pros and cons \\
\hline ZFN & 5. & 1985 & $\begin{array}{l}\text { 1. Zinc finger domain } \\
\text { 2. Fokk endonuclease } \\
\text { domain }\end{array}$ & $\begin{array}{l}\text { TFIllA } \\
\text { type II }\end{array}$ & DNA & $24 \cdot 36$ & $\begin{array}{l}\text { Indels and } \\
\text { substtutions }\end{array}$ & Fokl endonuclease & 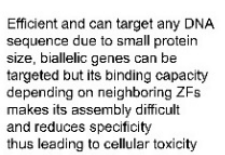 \\
\hline TALEN & 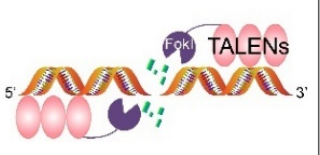 & 2009 & $\begin{array}{l}\text { 1. TALE } \\
\text { 2. Fok I usion protein }\end{array}$ & type III & DNA & 24.59 & $\begin{array}{l}\text { Indels and } \\
\text { substitutions }\end{array}$ & Fokl endonuclease & 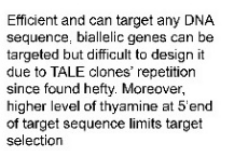 \\
\hline spCass & 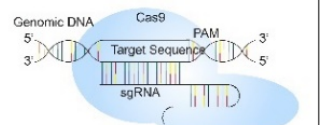 & 2013 & $\begin{array}{l}\text { 1. Cas9 protein, } \\
\text { 2. Donoror NAA and, } \\
\text { 3. sgRNA }\end{array}$ & $11 / 2$ & DNA, RNA & $19-22$ & $\begin{array}{l}\text { Large insertions, } \\
\text { deletions, replacements. } \\
\text { and iversions }\end{array}$ & $\begin{array}{l}\text { Cas nuclease, } \\
\text { Ruc and, } \\
\text { HNH }\end{array}$ & 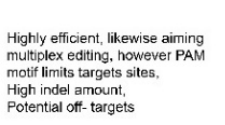 \\
\hline Cas12 & 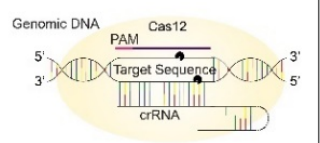 & 2015 & 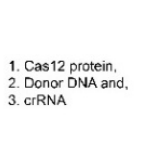 & $V-A / 2$ & DNA & $18-25$ & $\begin{array}{l}\text { Stochastic Indels, } \\
\text { multiplex editing }\end{array}$ & $\begin{array}{l}\text { Single nuclease site } \\
\text { (RuvC-Nuc) }\end{array}$ & 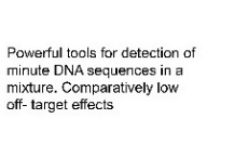 \\
\hline Cas13 & (GengNa & 2016 & $\begin{array}{l}\text { 1. crRNA and, } \\
\text { 2. Cas13 protein }\end{array}$ & $\mathrm{V} 1-0 / 2$ & RNA & $22-30$ & $\begin{array}{l}\text { Stochastic Indels, } \\
\text { multiplex editing }\end{array}$ & HEPN domain & 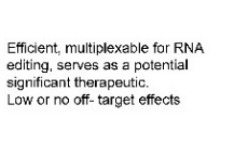 \\
\hline Base editing & $\begin{array}{c}\text { Cenomer } \\
5 \\
3 \\
3\end{array}$ & 2016 & $\begin{array}{l}\text { 1. Base editor } \\
\text { (tusion ciasng } \\
\text { + deaminase) and, } \\
\text { 2. sgR }\end{array}$ & $1 / 2$ & DNA, RNA & $15-20$ & $\begin{array}{l}\text { PAM distal transition/ } \\
\text { point mutation }\end{array}$ & Base editors (CBEs, ABEs) & 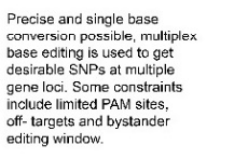 \\
\hline 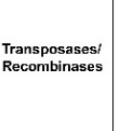 & 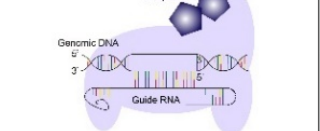 & 2019 & 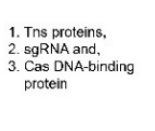 & - & DNA & $>30$ & $\begin{array}{l}\text { Large insertions, } \\
\text { deletions, replacements. } \\
\text { and iversions }\end{array}$ & 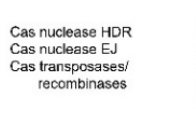 & 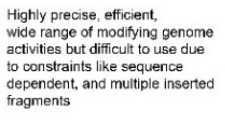 \\
\hline Prime editing & (II) & 2019 & $\begin{array}{l}\text { 1. Prime editor } \\
\text { (fusion Casan + RT) } \\
\text { and } \\
\text { 2. pegRNA }\end{array}$ & 1/2 2 & DNA & $1>30$ & $\begin{array}{l}\text { PAM proximal transitionl } \\
\text { point rutation, small } \\
\text { insertions and deletions }\end{array}$ & $\begin{array}{l}\text { Cas nuclease HDR } \\
\text { Prime editors }\end{array}$ & 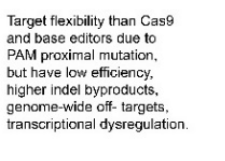 \\
\hline
\end{tabular}

Figure 2. Comparison between different components of various genome-editing tools. The figure presents the models of different genome editing systems, such as ZFN (zinc-finger nucleases), TALEN (transcription activator-like effector nucleases), spCas9 (streptococcus pyogenes CRISPR-associated protein 9), Cas12, Cas13, Base editing, Transposases or recombinases, and prime editing, their evolution, components, class or type of editing system, target nucleic acid, length of target sequence, type of mutations, reagents and methods, and their advantages and disadvantages. PAM, protospacer adjacent motif; sgRNA, single guide RNA; crRNA, CRISPR RNA; Tns Proteins, Transposases proteins; pegRNA, prime editing guide RNA; RT, Reverse Transcription; DNA, Deoxyribonucleic acid; RNA, Ribonucleic acid; RuvC, an endonuclease domain named for an Escherichia coli protein involved in DNA repair; $\mathrm{HNH}$, an endonuclease domain named for characteristic histidine and asparagine residues; HDR, homology-directed repair; indel, insertion and/or deletion; CBEs, cytosine base editors; ABEs, adenine base editors.

\section{CRISPR/Cas9 Based Rice Crop Improvement}

In the CRISPR/Cas9 genome editing system, Cas9 nuclease introduces double strand breaks (DSBs) in DNA at the sgRNA target site. These DSBs are repaired by the nonhomologous end joining (NHEJ) pathway that results in insertion or deletions (indels) at the target site, thus knocking out the targeted gene [12] (Figure 2). The CRISPR/Cas9 system is the most prevalent GET that has been used to improve several agronomic traits of rice, such as grain yield, abiotic stress tolerance, disease resistance, herbicide resistance, in addition to rice grain quality (Figure 3). Classical breeding requires selection of progenies 
for 6-7 years to obtain the desired level of homozygosity, while the CRISPR/Cas9 system delivers it within a year, making it a powerful plant breeding tool [12]. Herein, we discussed the applications of CRISPR/Cas9 for rice crop improvement.

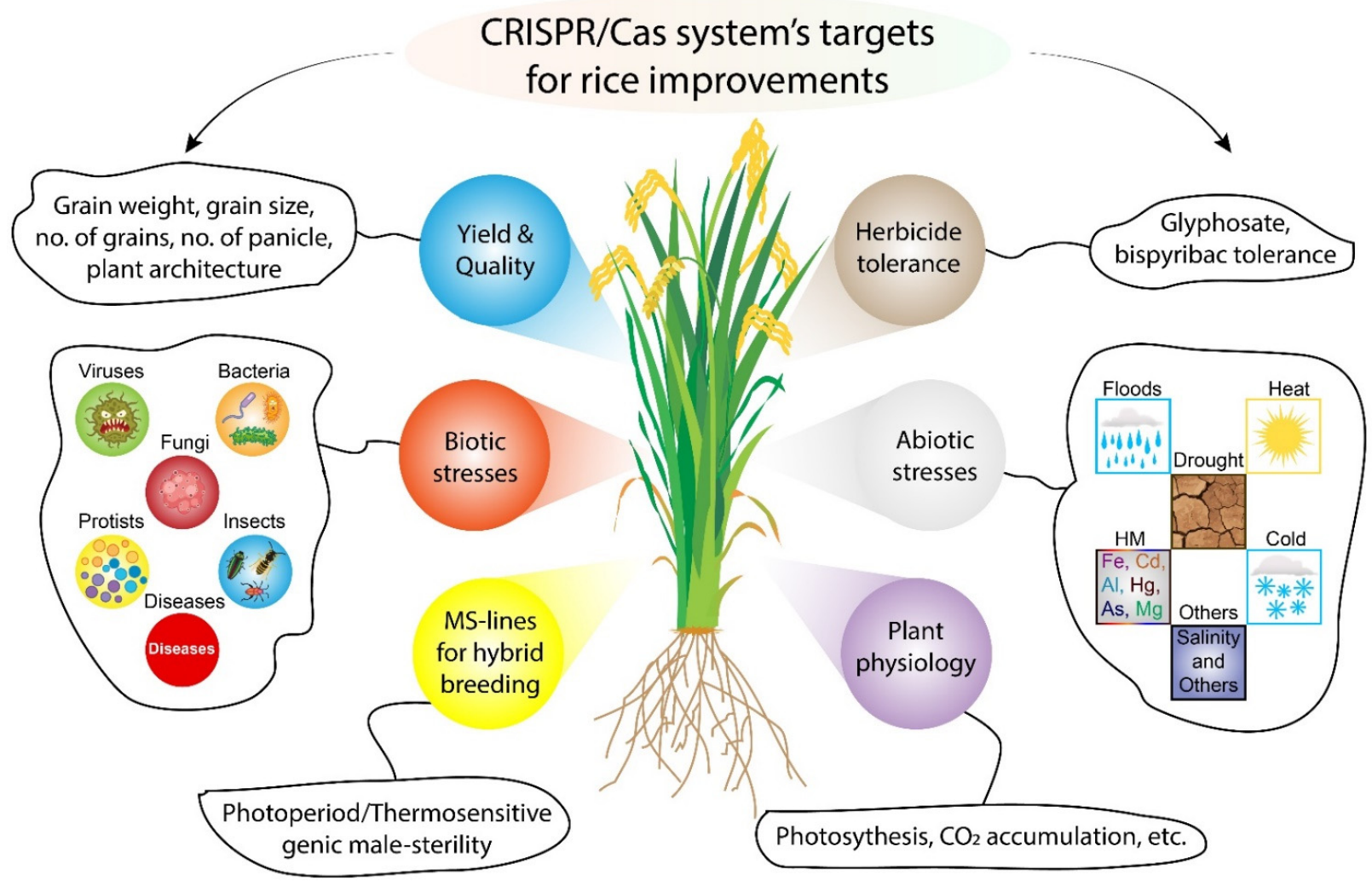

Figure 3. Potential targets of CRISPR/Cas systems for rice crop improvement. Rice can be improved by targeting any potential negative regulator of yield, quality, biotic and abiotic stress tolerance, and plant physiology. Male sterile (MS) lines can be developed for hybrid development by targeting potential genes such as Thermo-sensitive Male Sterility 5 gene. HM, Heavy Metal; Fe, Iron, Cd, Cadmium; Al, Aluminum; Hg, Mercury; As, Arsenic; Mg, Magnesium.

\subsection{CRISPR/Cas9 for Improving Grain Yield of Rice}

To date, three distinct strategies have been utilized for improving grain yield of rice by using CRISPR/Cas-based systems:

\subsubsection{Improving the Plant Architecture}

During the 1960s, manipulation of plant height genes in rice and wheat significantly decreased the plant height, resulting in improved lodging resistance and fertilizer responsiveness that led to considerable increase in grain yield. This is one of the most significant crop improvement events, known as 'the green revolution' [24]. Therefore, altering of rice plant architecture through identification of quantitative trait loci (QTL) and transgene transfer has been a prime breeding target for years [25-27]. With the additional benefits of being a robust and transgene-free system, CRISPR/Cas9 has been successfully used to alter the plant architecture by editing/knockout of genes/QTL coding for plant height and number of tillers i.e., semi dwarf 1 (SD1) [28], STRONG CULM3/TEOSINTE BRANCH1/FINE CULM1 (SCM3/OsTB1/FC1) [29], Gibberellin-20 oxidase-2 (OsGA20ox2) and SD1 [30].

CRISPR/Cas9-based mutations in two targets of the first codon of OsGA20ox2 reduced the flag leaf length, gibberellins level, and plant height (22.2\% reduction), and increased the grain yield by $6.0 \%$. Additionally, OsGA20ox2, fructose-bisphosphate aldolase 1, glyceraldehyde3-phosphate dehydrogenase, S-adenosyl methionine synthetase 1, and putative ATP synthase proteins were downregulated in semi-dwarf mutants [30]. Similarly, CRISPR mediated SD1 mutants had resistance to lodging, semi-dwarf plant height, and increased grain 
yield [28], while OsTB1/FC1 mutants showed increase in the number of tillers [29]. In another study, CRISPR/Cas9 mediated targeting of Ideal Plant Architecture 1 (IPA1) QTL resulted in reduced plant height and increase in number of tillers and, thus, increased the grain yield [31]. Similarly, targeting of rice fruit weight 4, OsFWL4 [32] with sgRNA/Cas9 led to increases in flag leaf area, grain length, number of tillers, and grain yield.

\subsubsection{Improving the Panicle Architecture}

Panicle morphology or architecture related traits, such as panicle length, panicle weight, panicle density, panicle orientation (erect or droopy), number of grains per panicle, grain weight, length, and size are the key factors that determine the final grain yield of rice [25-27] and, thus, have been a crucial target for high yielding rice. Several genes and/or QTL for panicle architecture traits has been targeted by the CRISPR/Cas9 system to improve the grain yield of rice (Table 1). For example, sgRNA/Cas9 mediated multiplexed editing of three panicle architecture regions, i.e., DENSE AN D ERECT PANICLE (DEP1), Grain Size 3 (GS3), Grain number 1a (Gn1a), and a plant architecture QTL, Ideal Plant Architecture1 (IPA1) resulted in improved panicle and plant architecture traits. The mutants had erect panicle, improved grain size, and number of grains, more/less number of tillers and reduced plant height, leading to improved grain yield [31]. Similarly, editing of panicle architecture genes, PIN family of auxin efflux carrier-like gene $5 b$ (OsPIN5b) genes by sgRNA/Cas9 system increased the panicle length in mutants as compared to wild type plants, thus increasing the rice grain yield [33], while multiplexed CRISPR mediated editing of Gn1a, DEP1 and GS3 increased the number of grains per panicle, panicle architecture, panicle orientation, grain size, and grain yield [34,35]. Additionally, CRISPR based targeting of grain width/weight 2, 5, 6 and 8 (GW2, GW5, GW6, and GW8) and GS3 [36-39] resulted in enhanced grain width, weight, size, and grain yield.

Table 1. Key examples of application of CRISPR/Cas9 system for improving rice grain yield and related traits.

\begin{tabular}{|c|c|c|c|c|c|}
\hline Targeted Trait & Targeted Gene/s & Cas9 Promoter/S & sgRNA Promoter/S & Improved Trait/s in Mutants & Ref \\
\hline \multirow{5}{*}{$\begin{array}{c}\text { Plant } \\
\text { Architecture }\end{array}$} & SD1 & $2 \times 35 S$ pro & $\begin{array}{l}\text { gRNA1 }^{\text {SD1 }} \\
\text { gRNA3 }^{\text {SE5 }}\end{array}$ & $\begin{array}{c}\text { Grain yield, plant architecture, } \\
\text { semi-dwarf plants, resistance to } \\
\text { lodging }\end{array}$ & [28] \\
\hline & OsGA20ox2 & Pubi-H & OsU6a OsU6b & $\begin{array}{l}\text { Grain yield, plant architecture, } \\
\text { semi-dwarf plants, reduced } \\
\text { gibberellins and flag leaf length }\end{array}$ & {$[30]$} \\
\hline & $\begin{array}{c}\text { SCM1/SD1, } \\
\text { SCM3/OsTB1/FC1, } \\
\text { SCM2/APO1 }\end{array}$ & $\begin{array}{l}2 \times 35 \text { S pro } \\
\text { CaMV }\end{array}$ & $\begin{array}{l}\text { gRNA1, gRNA2, } \\
\text { gRNA3, gRNA4, } \\
\text { gRNA5, gRNA6 }\end{array}$ & $\begin{array}{l}\text { Plant architecture, number of tillers, } \\
\text { panicle architecture, larger panicles, } \\
\text { stem cross-section area }\end{array}$ & [29] \\
\hline & OsFWL4 & Maize Ubi1 & OsU6 & $\begin{array}{l}\text { Grain yield, plant architecture, } \\
\text { number of tillers, flag leaf area, grain } \\
\text { length, number of cells in flag leaf }\end{array}$ & {$[32]$} \\
\hline & IPA1 & Maize Ubi1 & U6a & $\begin{array}{c}\text { Grain yield, plant architecture, } \\
\text { number of tillers, reduced plant } \\
\text { height }\end{array}$ & [31] \\
\hline \multirow{5}{*}{$\begin{array}{c}\text { Panicle } \\
\text { Architecture }\end{array}$} & $\begin{array}{l}\text { IPA1, GS3, DEP1, } \\
\text { Gn1a }\end{array}$ & Maize Ubi1 & U6a & $\begin{array}{c}\text { Grain yield, plant architecture, panicle } \\
\text { architecture, number of tillers, grain } \\
\text { size, dense erect panicles, grain } \\
\text { number }\end{array}$ & {$[31]$} \\
\hline & GS3, OsGW2, Gn1a & p35S & $\begin{array}{l}\text { OsU6 } \\
\text { OsU3 }\end{array}$ & $\begin{array}{l}\text { Grain yield, grain size, grain weight, } \\
\text { number of grains per panicle }\end{array}$ & {$[37]$} \\
\hline & OsPIN5b, GS3 & $\begin{array}{l}2 \times 35 \text { S pro } \\
\text { Pubi-H }\end{array}$ & OsU6a & $\begin{array}{l}\text { Grain yield, panicle architecture, } \\
\text { panicle length, grain size }\end{array}$ & {$[33]$} \\
\hline & GW2, 5 and 6 & pUBQ & OsU3, OsU6 TaU3 & Grain yield, grain weight & [36] \\
\hline & OsSPL16/qGW8 & $\begin{array}{l}2 \times 35 \text { S pro } \\
\text { Pubi }\end{array}$ & OsU6a & Grain yield, grain weight, grain size & {$[38]$} \\
\hline
\end{tabular}


Table 1. Cont

\begin{tabular}{|c|c|c|c|c|c|}
\hline Targeted Trait & Targeted Gene/s & Cas9 Promoter/S & sgRNA Promoter/S & Improved Trait/s in Mutants & Ref. \\
\hline & Gn1a, GS3 & $2 \times 35 S$ pro & U3 & $\begin{array}{c}\text { Grain yield, panicle architecture, } \\
\text { number of grains per panicle, grain } \\
\text { size }\end{array}$ & {$[35]$} \\
\hline & $G n 1 a, D E P 1$ & $2 \times 35 S$ pro & OsU3 & $\begin{array}{c}\text { Grain yield, panicle architecture, } \\
\text { panicle orientation, number of grains } \\
\text { per panicle }\end{array}$ & {$[34]$} \\
\hline & $\begin{array}{l}\text { Cytochrome P450, } \\
\text { OsBADH2 }\end{array}$ & Pubi-H & $\begin{array}{l}\text { U6a } \\
\text { U6b } \\
\text { U6c } \\
\text { U3m }\end{array}$ & $\begin{array}{l}\text { Grain yield, grain size, aroma } \\
\text { (2-acetyl-1-pyrroline (2AP) content) }\end{array}$ & [39] \\
\hline \multirow{2}{*}{$\begin{array}{l}\text { ABA Signaling } \\
\text { Pathway }\end{array}$} & PYL1, PYL4, PYL6 & Maize Ubi1 & $\begin{array}{l}\text { OsU6 } \\
\text { OsU3 }\end{array}$ & Number of grains, grain yield & [41] \\
\hline & OsPYL9 & PubiH & $\begin{array}{l}\text { OsU6a } \\
\text { OsU6b }\end{array}$ & $\begin{array}{l}\text { Grain yield under normal and limited } \\
\text { water availability }\end{array}$ & [40] \\
\hline
\end{tabular}

\subsubsection{Improving the ABA Signaling Pathway}

Abscisic acid (ABA) is an important plant hormone that plays an important role in germination, stress response, plant growth, and development, thus altering the ABA signaling pathway has been an important breeding target [4]. Indeed, CRISPR/Cas9 system based targeting of ABA receptor gene Pyrabactin Resistance 9 (OsPYL9) [40] increased the grain yield and editing of three genes, PYL1, PYL4, and PYL6 [41], increased the number of grains by $31 \%$, leading to higher yield in mutants than wild type plants. Thus, this novel approach highlights the potential of manipulation of signaling to increase the grain yield and ensure food security.

\subsection{CRISPR/Cas9 for Abiotic Stress Tolerant Rice}

Constant rise in global temperature is causing global warming, or climate change, leading to more frequent drought spells and soil salinization [4], thus threatening crop production. Rice faces several abiotic stresses during its life cycle and drought is the most eminent threat to rice production. This is due to the fact that $3000 \mathrm{~L}$ of water is needed to produce $1 \mathrm{~kg}$ rice grains, but a shallow root system and a thin cuticle makes it one of the most drought-susceptible plants that could face 100\% yield loss [5]. Similarly, for rice plants grown in the highlands of China, Japan, Korea, etc., cold temperatures during reproduction adversely affect the rice grain yield and quality [1]. Additionally, rice is more susceptible to salt stress as compared to other cereals, such as wheat [42]; thus, rice production could be reduced across the globe by $50 \%$ [6]. The situation becomes complicated as drought and salinity tolerance are complex traits that are conferred by several genes, proteins, transporter proteins, transcription factors (TFs), ion transporters, microRNAs (miRNAs), hormones, metabolites, and ions [4,43]. Therefore, classical breeding has limited success and power to accumulate these genes in cultivars and development of abiotic stress tolerant plants. Being a powerful tool that can target any gene in any organism, the CRISRP/Cas9 system has been successfully utilized to improve abiotic stress tolerance in corn, rice, tomato, wheat, Arabidopsis thaliana, and Physcomitrella patens [12,44]. Indeed, several groups have successfully demonstrated the power of CRISPR/Cas9 system for development of climate resilient (drought, salinity, cold, and osmotic stress tolerant) rice (Table 2). Their outcomes and CRISPR-based approaches for the purpose are described below.

\subsubsection{Targeting the ABA Signaling Pathway}

$\mathrm{ABA}$ is the first line of defense against drought stress and its production is one of the first responses to drought stress in plants. Subsequently, plants respond to drought stress through ABA-dependent or independent signaling cascades [4]. CRISPR/Cas9-mediated knockout of osmotic stress/ABA-activated protein kinase 2, OsSAPK2, revealed that OsSAPK2 has roles in ABA-mediated seed dormancy, drought, salinity, and osmotic stress tolerance 
to rice through ABA signaling, scavenging of reactive oxygen species (ROS), stomatal closure through accumulation of compatible solutes, and upregulating stress-related genes (OsLEA3, OsbZIP23, OsRab16b, OsRab21, OsOREB1, and slow anion channels, OsSLAC1 and OsSLAC7). The mutant plants were more susceptible to stresses, but this revealed the critical role of OsSAPK2 in ABA signaling cascade [45]. Similarly, CRISPR/Cas9 system was used to target ABA receptor gene, OSPYL9 [40], and mutant rice plants had improved drought tolerance due to a reduced number of stomata, stomatal conductance, transpiration rate, and malondialdehyde (MDA) content and enhanced cuticle wax, panicle number, abscisic acid (ABA) content, catalase (CAT), superoxide dismutase (SOD), and survival rate as compared to wild type plants. Drought tolerance in rice was also improved by sgRNA/Cas9 based targeting of Enhanced Response to ABA1 (ERA1) [46] through regulating the stomatal conductance.

\subsubsection{Improving the Leaf Morphology}

Leaf controls evapotranspiration, an important parameter for drought tolerance. Therefore, altering the leaf morphology is a key strategy to improve grain yield and drought tolerance in plants. CRISPR/Cas9-based multiplexed editing of SEMI-ROLLED LEAF 1 and 2 (OsSRL1 and OsSRL2) [47] conferred drought tolerance to rice. The mutants had curled leaves, reduced number of stomata, stomatal conductance, transpiration rate, and malondialdehyde (MDA) content, as compared to wild types plants. Additionally, mutants had a higher panicle number, abscisic acid (ABA) content, catalase (CAT), superoxide dismutase (SOD), and survival rate.

\subsubsection{Targeting the microRNA and Transcription Factors}

The miRNAs and TFs are the key regulators of stress related genes and either upor-down-regulate the key genes involved in abiotic stress tolerance mechanisms [4,48]. Therefore, knockout of TFs negatively regulating the tolerance related genes is a reliable strategy to increase abiotic stress tolerance in rice. Indeed, CRISPR/Cas9 mediated knockout of the R2R3-type MYB transcription factor, OsMYB30 [32] increased the grain yield and cold tolerance in mutants as compared to wild type rice plants. Similarly, CRISPR/Cas9 mediated knockout of a zinc finger TF, drought and salt tolerance (DST) [49], and a miRNA, OsmiR535 [50], in two independent studies, enhanced drought, salinity, and osmotic stress tolerance in mutants as compared to wild type plants. The abiotic stress tolerance in mutants was conferred by improvement in stomatal conductance, enhanced leaf water retention; leaf, root, and shoot architecture [49,50], as detailed in Table 2. Additionally, sgRNA/Cas9 system based knockout of amino acid B-type response regulator TF, OsRR22 [51] conferred salinity tolerance in mutants by improving the shoot architecture; thus, highlighting the utility of TF targeting for improving abiotic stress tolerance in rice.

Table 2. Examples of CRISPR/Cas9 system for enhancing abiotic stress tolerance of rice.

\begin{tabular}{|c|c|c|c|c|c|}
\hline Stress & Edited Gene/S & Cas9 Promoter/S & sgRNA Promoter/S & Improved Traits in Mutants & Ref. \\
\hline \multirow{3}{*}{ Drought } & OsSAPK2 & Pubi-H & U3 & $\begin{array}{l}\text { Reduced drought, salinity, and osmotic stress } \\
\text { tolerance; role of gene in ROS scavenging, } \\
\text { stomatal conductance and ABA signaling }\end{array}$ & {$[45]$} \\
\hline & OsPYL9 & PubiH & $\begin{array}{l}\text { OsU6a } \\
\text { OsU6b }\end{array}$ & $\begin{array}{l}\text { Drought tolerance; grain yield, antioxidant } \\
\text { activities, chlorophyll content, ABA } \\
\text { accumulation, leaf cuticle wax, survival rate, } \\
\text { stomatal conductance, transpiration rate }\end{array}$ & [40] \\
\hline & OsERA1 & Not defined & pCAMBIA1300 & $\begin{array}{l}\text { Drought tolerance, stomatal conductance, } \\
\text { increased sensitivity to ABA. }\end{array}$ & [46] \\
\hline
\end{tabular}


Table 2. Cont.

\begin{tabular}{|c|c|c|c|c|c|}
\hline Stress & Edited Gene/S & Cas9 Promoter/S & sgRNA Promoter/S & Improved Traits in Mutants & Ref. \\
\hline & $\begin{array}{l}\text { OsSRL1, } \\
\text { OsSRL2 }\end{array}$ & Pubi-H & $\begin{array}{l}\text { U6a } \\
\text { U6b } \\
\text { U6c } \\
\text { U3m }\end{array}$ & $\begin{array}{l}\text { Improved drought tolerance; Reduced number } \\
\text { of stomata, stomatal conductance, transpiration } \\
\text { rate and malondialdehyde (MDA) content; } \\
\text { Improved panicle number, abscisic acid (ABA) } \\
\text { content, catalase (CAT), superoxide dismutase } \\
\text { (SOD) and survival rate }\end{array}$ & {$[47]$} \\
\hline & DST & OsUBQ & OsU3 & $\begin{array}{l}\text { Drought tolerance, leaf architecture, reduced } \\
\text { stomatal density, enhanced leaf water retention }\end{array}$ & [49] \\
\hline & OsmiR535 & $\begin{array}{c}\text { UBI } \\
35 S \text { pro }\end{array}$ & $\begin{array}{l}\text { OsU3 } \\
\text { OsU6 }\end{array}$ & $\begin{array}{c}\text { Drought tolerance, ABA insensitivity, number of } \\
\text { lateral roots }(73 \% \text { more), shoot length }(30 \% \\
\text { longer), primary root length }\end{array}$ & {$[50]$} \\
\hline \multirow{4}{*}{$\begin{array}{l}\text { Salinity } \\
\text { and } \\
\text { Osmotic } \\
\text { Stress }\end{array}$} & OsSAPK2 & Pubi-H & U3 & $\begin{array}{l}\text { Reduced salinity and osmotic stress tolerance, } \\
\text { role of gene in ROS scavenging }\end{array}$ & {$[45]$} \\
\hline & OsRR22 & $\begin{array}{l}2 \times 35 S \text { pro } \\
\text { Pubi-H }\end{array}$ & OsU6a & $\begin{array}{l}\text { Salinity tolerance, shoot length, shoot fresh and } \\
\text { dry weight }\end{array}$ & [51] \\
\hline & DST & OsUBQ & OsU3 & Salinity tolerance, osmotic tolerance & [49] \\
\hline & OsmiR535 & $\begin{array}{c}\text { UBI } \\
35 S \text { pro }\end{array}$ & $\begin{array}{l}\text { OsU3 } \\
\text { OsU6 }\end{array}$ & $\begin{array}{c}\text { Salinity tolerance, osmotic tolerance, shoot } \\
\text { length }(86.8 \%) \text {, number of lateral roots }(514 \% \text { as } \\
\text { compared with line overexpressing MIR535), } \\
\text { primary root length }(35.8 \%)\end{array}$ & {$[50]$} \\
\hline \multirow{2}{*}{ Cold Stress } & OsAnn3 & $\begin{array}{c}\text { UBI } \\
35 S \text { pro }\end{array}$ & U3 & Response to cold tolerance & [52] \\
\hline & OsMYB30 & $\begin{array}{l}2 \times 35 S \text { pro } \\
\text { Pubi-H }\end{array}$ & OsU6a & Cold tolerance & {$[33]$} \\
\hline
\end{tabular}

\subsection{CRISPR/Cas9 for Improving Disease Resistance of Rice}

Potato blight in Ireland (also known as the Great Famine or the Irish Potato Famine) during 1845-1853, the Great Bengal Famine during 1943, and maize leaf bight in the USA during 1969-1970 are examples of crop failure due to plant diseases. Some of these events resulted in the deaths and migration of millions [24]. Over 800 million people are underfed across the globe due to plant diseases [24]; thus are a threat to food security. Among the various diseases faced by rice, bacterial leaf blight (BLB), caused by a bacteria Xanthomonas oryzae $p v$. Oryza, is one of the most devastating diseases that can reduce the grain yield by 70\% (http: / / www.knowledgebank.irri.org, accessed on 29 June 2021). Similarly, Magnaporthe oryzae fungus causes rice blast disease that could result in 30-100\% yield loss [53]. Therefore, management of rice diseases is crucial to feed the growing population.

Improving plant disease resistance through classical breeding approaches, such as back crossing breeding, multiline breeding, and stacking of resistance (R) gene/s, is a lengthy and tedious process that consumes years $[54,55]$. Whereas, targeting of different susceptibility (S) factors and gene/s through the CRISPR/Cas9 system has fast-forwarded the development of broad-spectrum disease resistance within a year [12,56-60]. Undoubtedly, CRISPR/Cas9 technology has been utilized to develop broad-spectrum resistance against several bacteria, fungi, and viruses (Table 3). In rice, two distinct CRISPR/Cas9mediated approaches has been used to improve disease resistance.

\subsubsection{Gene Disruption by Targeting the Coding Sequence}

This strategy involves the disruption of the coding sequence of S genes and CRISPR/ Cas9 is used to create indels in one or multiple nucleotides of exon/s to knockout a particular gene. The most prevalent application of the CRISPR/Cas9 system for disease resistance is to knockout the $S$ genes by targeting the coding sequence (CDS), e.g., gene knockout by targeting the CDS or exons of Ethylene Response Factor, OsERF922 [61], polyketide synthaseencoding genes, OsRSY1, and OsALB1 [62], and PYRICULARIA ORYZAE RESISTANCE 21 (Pi21) $[63,64]$ enhanced resistance against rice blast, $M$. oryzae. Similarly, CRISPR mediated targeting of CDS or exons of Sugar Will Eventually be Exported Transporters (SWEET) gene 
family members, OsSWEET11 (also called Os8N3) [65] and OsSWEET14 [58] increased the resistance against bacterial leaf blight (BLB) caused by X oryzae pv. Oryzae (XOO). Moreover, targeting of $e I F 4 G$ [66], a host $S$ gene improved the resistance against or rice tungro disease (RTD) caused by rice tungro spherical virus (RTSV). The disease resistance was observed in terms of less disease symptoms, improved yield, and agronomic performance.

Table 3. Examples of CRISPR/Cas9 system for enhancing the disease resistance of rice.

\begin{tabular}{|c|c|c|c|c|c|}
\hline Pathogen & $\begin{array}{c}\text { Improved } \\
\text { Disease/Pathogen } \\
\text { Resistance }\end{array}$ & Targeted Gene/S & Cas9 Promoter/S & sgRNA Promoter/S & Ref. \\
\hline \multirow{4}{*}{ Fungi } & \multirow{4}{*}{$\begin{array}{c}\text { Rice blast } \\
\text { (Magnaporthe oryzae) }\end{array}$} & OsERF922 & $\begin{array}{c}2 \times 35 S \text { pro } \\
\text { Pubi-H }\end{array}$ & OsU6a & [61] \\
\hline & & OsALB1, OsRSY1, & TrpC, TEF1 & $\begin{array}{l}\text { SNR52, U6-1, } \\
\text { U6-2 }\end{array}$ & {$[62]$} \\
\hline & & OsPi21 & PubiH & OsU6a, OsU3 & [63] \\
\hline & & OsPi21 & PubiH & OsU6a, OsU6b & {$[64]$} \\
\hline \multirow{8}{*}{ Bacteria } & \multirow{8}{*}{$\begin{array}{c}\text { Bacterial leaf blight } \\
\text { (Xanthomonas oryzae } \\
\text { pv. Oryzae) }\end{array}$} & $\begin{array}{l}\text { OsSWEET14, } \\
\text { OsSWEET11 }\end{array}$ & CaMV35S & U6 & [67] \\
\hline & & $\begin{array}{c}\text { OsSWEET11 or } \\
\text { Os } 8 N 3\end{array}$ & 35S-p & OsU6a & [65] \\
\hline & & OsXa13/SWEET11 & PubiH & OsU6a, OsU3 & [63] \\
\hline & & $\begin{array}{l}\text { OsSWEET11, } \\
\text { OsSWEET13, } \\
\text { OsSWEET14 }\end{array}$ & ZmUbiP & U6 & [56] \\
\hline & & $\begin{array}{l}\text { OsSWEET11, } \\
\text { OsSWEET14 }\end{array}$ & 35S CaMV & SW11, SW14 & [57] \\
\hline & & OsSWEET14 & Pubi or P35S & OsU3, OsU6b, OsU6c & [58] \\
\hline & & OsSWEET14 & 35S, Ubi & OsU3 & [59] \\
\hline & & OsXa13/SWEET11 & 35S, Ubi & $\mathrm{U} 3, \mathrm{U} 6 \mathrm{a}$ & [68] \\
\hline Virus & $\begin{array}{c}\text { Rice tungro spherical } \\
\text { virus (RTSV) }\end{array}$ & eIF4G & $\begin{array}{l}\text { ZmUBI1, } \\
\text { CaMV35S }\end{array}$ & TaU6 & [66] \\
\hline
\end{tabular}

\subsubsection{Gene Disruption via Promotor Sequence}

CRISPR/Cas9 based editing of the promoter sequences of $S$ genes results in blockage of gene expression. The approach is editing of the effector-binding site that makes it impossible for the pathogen-binding site to bind the promotor sequence, thus conferring disease resistance. Certainly, one of the pioneer applications of CRISPR/Cas9 system in plants in 2013 was editing in the promoter region of sugar transporter genes OsSWEET11 and OsSWEET14 [67]. Subsequently, CRISPR-mediated targeting of the promoter region of OsSWEET14 [59], WEET11/Xa13 [63,68], and multiplex editing of OsSWEET11 OsSWEET13 and OsSWEET14 $[56,57]$ genes improved BLB tolerance in rice by avoiding the contact of Xoo with $S$ genes.

\subsection{CRISPR/Cas9 for Herbicide Resistant Rice}

Several herbicides, such as 'Basta', and glyphosate N-(phosphonomethyl) glycine are used to kill weeds in over 130 countries [69]. It is important that herbicides just kill the weeds and not the crop plants. Traditionally, DNA recombinant technology or a transgenic approach has been utilized extensively to improve herbicide resistance in corn, cotton, and soybean $[69,70]$. Due to rigorous biosafety checks for genetically modified organisms (GMO) or transgenic plants, CRISPR/Cas9-mediated herbicide resistance has become more popular in recent years [18,48,71,72]. For example, CRISPR/Cas9-mediated knockout of the Acetolactate Synthase (OsALS) [73] gene conferred resistance against and imazapic (IMP) and imazethapyr (IMT) in mutant rice plants. Similarly, knockout of the OsALS gene [72] and multiplexed editing of OsALS and FTIP1e genes [18] led to increased resistance against 
bispyribac sodium and imazamox pesticides, respectively. Moreover, a novel CRISPR/Cas9 mediated knock-in/replacement of 5-enolpyruvylshikimate-3-phosphate synthase (OsEPSPS) gene [71] increased the glyphosate resistance in rice.

\subsection{CRISPR/Cas9 for Improving Rice Quality Parameters}

Rice grain quality depends on the characteristics that could meet consumer demands and preferences. The grain quality parameters of rice include physical appearance, milling quality, cooking, eating, and some nutritional qualities [2]. The application of the CRISPR/Cas9 system for rice grain quality improvement has speeded up rice breeding with desirable traits (Figure 4).

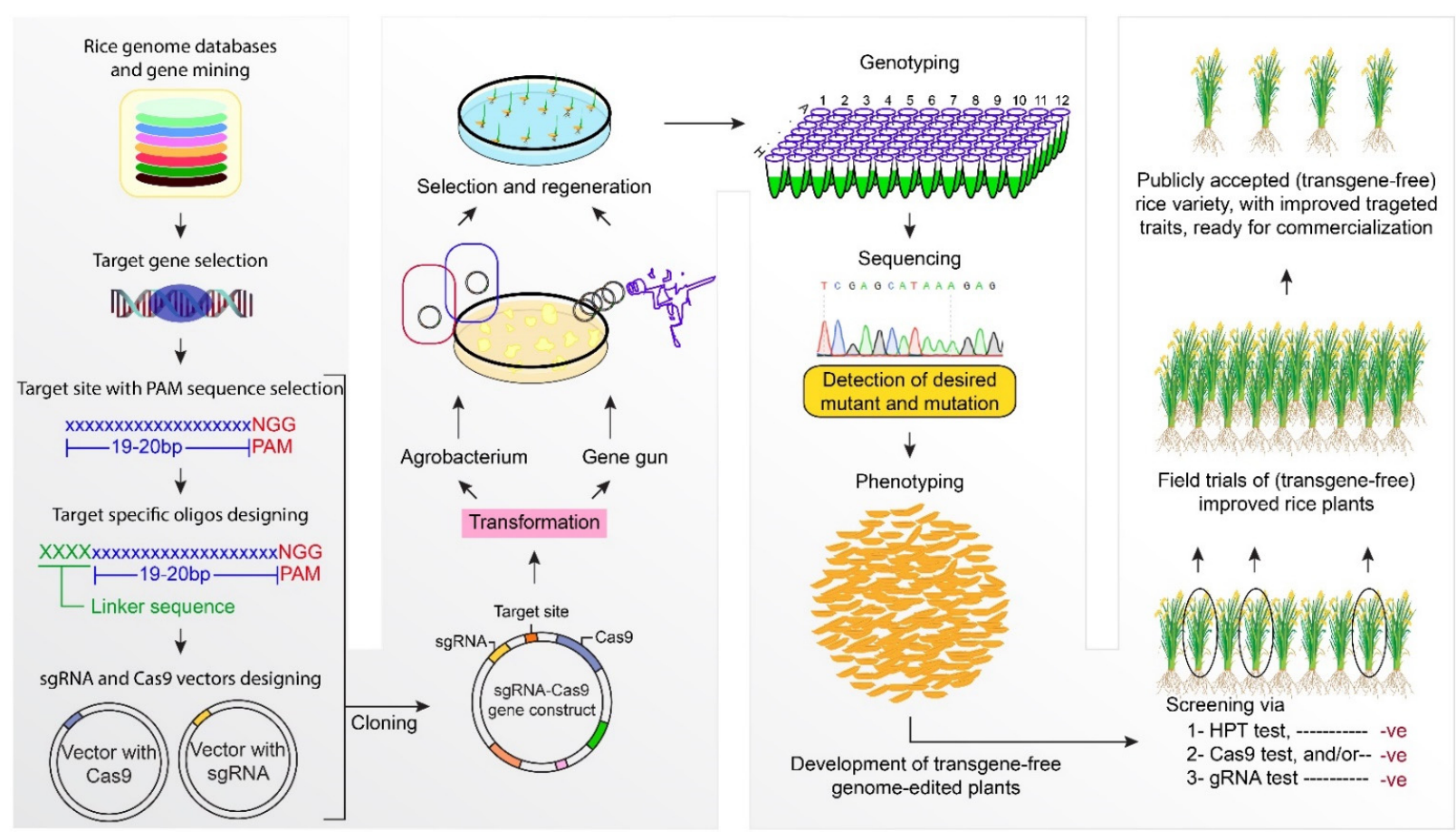

Figure 4. General strategy and stepwise method of development of transgene-free new rice variety with improved desirable traits using genome-editing tools. The process starts with the rice genome databases surfing and gene mining. After selecting the target gene, target site with PAM sequence (NGG) is selected. Then linker sequence (presented in green color) is added on the $5^{\prime}$ of the target site. Then vectors (Cas9 and sgRNA) are constructed and cloned into a new vector that carry the cauliflower mosaic virus promoter (CaMV 35S) promoter and vector backbone. Afterwards, the CRISPR/Cas9 construct carrying the target sequence is transformed into rice via a gene gun or the agrobacterium-mediated transformation method. Positive seedlings are screened and phenotyped. Detection of transgene-free plants occurred via HPT (Hygromycin) test, Cas9 or sgRNA test. Afterwards, only transgene-free plants will be further tested in field trials and commercialized.

\subsubsection{Cooking and Eating Quality Traits}

Eating and cooking quality (ECQ) traits are at the top of the list due to consumer choices and the economic value of rice [7]. Rice grain endosperm is made up of starch, due to which, grain quality relies on the physicochemical properties of rice endosperm covering amylose content (AC), gel consistency, gelatinization (GT). Genome editing techniques have been used to conduct several successful studies targeting traits for rice grain quality [74]. In the endosperm, $\mathrm{AC}$ and GT are regulated by the waxy or $W x$ gene, disease resistance protein RPM1 (RSR1) and soluble starch synthase IIa (ALK/SSIIa), respectively [75]. The Wx gene expression is controlled by a tetratricopeptide domain-containing FLOURY ENDOSPERM2, FLO2 protein, and some other TF like RSR1, granule bound starch synthase (GBSS1), a MYCtranscription factor (OsBP-5), basic helix-loop-helix (OsbHLH071), Ethylene responsive protein (OsEBP-89), basic leucine zipper58 (OsbZIP58), and MADS-box transcription factor 57, OsMADS7 [76]. CRISPR/Cas9 was used to introduce a loss-of-function mutation in 
the $W x$ gene for reducing AC in widely cultivated japonica cultivars, Xiushui134, and Wuyunjing7 [77]. Such mutations lead to the development of elite cultivars of desired traits without disturbing other traits. Recently, six novel $W x$ alleles have been generated by targeting the $W x b$ promoter to reduce $A C$ in rice grain. These alleles provide a range of $\mathrm{AC}$ that can be further used to improve rice quality worldwide according to local environmental conditions and consumer demand [78]. Similarly, ECQ of rice grain has improved by targeting putative amino acid transporter 6 and 10 (OsAAP6 and OsAAP10) through CRISPR/Cas9 mutation. Mutants developed by knocking out the genes are transgene-free with reduced grain protein content (GPC), AC, and glutelin content, but improved ECQ and starch content in T1 generation, measured by Rapid Visco Analysis [79].

Starch synthesis is regulated by many genes/enzymes, making it hard to alter starch content through conventional breeding. The gene editing of starch branching enzyme 1 and 2, SBEI, and SBEII, resulted in increased AC and resistant starch [80]; thus, offering health benefits. Similarly, CRISPR/Cas9-based mutated Betaine aldehyde dehydrogenase 2. Badh2 gene (an addition of $\mathrm{T}$ base in the first exon of $B a d h 2$ gene, responsible for fragrance) in Zhonghua 11, enhanced the fragrance in rice, a desirable cooking trait [81]. In another study, isoamylase-type debranching enzyme (ISA), responsible for amylopectin synthesis, was mutated via CRISPR/Cas9, creating ISA-1 deficient mutants (isa1), to improve grain quality with a change in expression of the gene/s associated to starch synthesis, total soluble sugar, and grain weight [82]. Further details about gene functions, cultivar background, Cas9, and sgRNA promotors for improving rice grain quality are provided in Table 4.

\subsubsection{Physical Appearance and Milling Quality}

Rice grain appearance and color is an important quality trait that determines the rice market acceptability [2]. Many genes, for grain size and shape affecting yield and quality, have been discovered, having the potential to be improved by CRISPR technology (Tables 1 and 4). Chalkiness is an undesirable attribute related to large grain size, resulting in high yield but poor quality, as it negatively affects the grain appearance and milling [83]. The GS9 gene (grain shape gene on chromosome 9) has been modified via CRISPR/Cas9 as gs 9 allele in Nipponbare by improving grain shape and appearance quality, while chalkiness was significantly reduced [84].

Grain length and size are important appearance quality parameters and many rice consumers prefer longer grains. CRISPR/Cas9-based editing of GS3 (GRAIN SIZE 3) has been used to increase the grain size and length [31,33]. Recently, CRISPR/Cas9-mediated mutagenesis of three cytochrome P450 including (Os03g0603100, Os03g0568400, and GL3.2) and $\mathrm{OsBADH} 2$ genes led to increase in grain size and fragrance [39]. In another study, CRSISPR based editing of the OsFWL4 gene significantly increased the rice grain length [32]; thus, increasing the consumer acceptability.

\subsubsection{Nutritional Quality Traits}

Iron $(\mathrm{Fe})$, zinc $(\mathrm{Zn})$, iodine, vitamin $\mathrm{A}$, folate or vitamin $\mathrm{B}_{9}$, proteins, fats, and amino acids are essential for human health, and their deficiency could increase the risk of depression, obesity, anemia, type II diabetes, pregnancy related complications, cancers, and cardiovascular disease [2]. Tilling based mutations in DNA demethylase gene, OsROS1 or TA2 resulted in enhanced antioxidants, lipids, phenolic, proteins, dietary fiber, vitamins (A, B1, B2, B3, B6, and E), and minerals (calcium, Fe and Zn) in rice grain [85]. However, large populations are required TILLING mutant screens due to low editing efficiency. Therefore, CRSIPR/Cas9 system with high efficiency has been used for the purpose. For example, CRSIRP/Cas9 based knockout of the Manganese/metal transporter 5 (OsNramp5) gene resulted in a more than six-fold reduced accumulation of toxic metal, cadmium (Cd), in rice grain [86], while copper accumulation increased and $\mathrm{Zn}$ concentration remained unchanged, as compared to wild type plants. Similarly, CRSIRP based editing of OsNramp5 produced the similar results [87] as detailed in Table 4. Additionally, CRISPR-Cas9 knocked out of inositol 1,3,4-trisphosphate 1/6-kinase (OsITPK1-6) led to low phytic acid accumula- 
tion in the rice grain and ultimately increased the inorganic phosphorus availability [88]. Moreover, CRISPR mediated knockout of the rice Orange (OsOr) gene [89], and insertion of Calreticulin 1 (SSU-crtI) and Phytoene synthase (ZmPsy) genes [90] resulted in increased $\beta$-carotene or provitamin $A$ in rice that must be an useful alternative to brown rice.

Table 4. Key applications of CRISPR/Cas9 system for improving rice grain quality.

\begin{tabular}{|c|c|c|c|c|c|c|c|}
\hline Quality Traits & $\begin{array}{c}\text { Cultivar } \\
\text { Background }\end{array}$ & Targeted Gene & Gene Function & Cas9 Promoter & $\begin{array}{l}\text { sgRNA } \\
\text { Promoter }\end{array}$ & Results & Ref. \\
\hline \multirow{8}{*}{$\begin{array}{l}\text { Eating andcook- } \\
\text { ingquality }\end{array}$} & $\begin{array}{c}\text { Yanggeng-158 } \\
\text { Nangeng-9108 } \\
\text { Wuyungeng-30 }\end{array}$ & $\begin{array}{l}\text { OsAAP6 } \\
\text { OsAAP10 }\end{array}$ & $\begin{array}{l}\text { Amino acid } \\
\text { transporter for } \\
\text { GPC }\end{array}$ & CaMV35S & OsU3 & $\begin{array}{l}\text { Improved eating and } \\
\text { cooking quality }\end{array}$ & [79] \\
\hline & $\begin{array}{l}\text { Zhonghua11, } \\
\text { XS134 }\end{array}$ & OsWaxy & $\begin{array}{l}\text { GBSS (amylose } \\
\text { synthesis) }\end{array}$ & CaMV35S & OsU6 & $\begin{array}{l}\text { Decrease in amylose } \\
\text { content (glutinous rice) }\end{array}$ & [78] \\
\hline & XS134 (Japonica) & OsWaxy & $\begin{array}{l}\text { GBSS (amylose } \\
\text { synthesis) }\end{array}$ & CaMV35S & OsU6 & $\begin{array}{l}\text { Decrease in amylose } \\
\text { content (glutinous rice) }\end{array}$ & [77] \\
\hline & $\begin{array}{l}\text { Kitaake } \\
\text { (Japonica) }\end{array}$ & $\begin{array}{l}\text { OsBEIand } \\
\text { OsBEIIb }\end{array}$ & $\begin{array}{l}\text { Starch branching } \\
\text { enzyme }\end{array}$ & pCXUN & OsU3 & High amylose content & [80] \\
\hline & Zhonghua11 & ISA1 & $\begin{array}{c}\text { Starch } \\
\text { (isoamylase- } \\
\text { type) } \\
\text { debranching } \\
\text { enzymes }\end{array}$ & CaMV 35S & OsU6 & $\begin{array}{c}\text { Reduced amylose } \\
\text { content; increased total } \\
\text { soluble sugar }\end{array}$ & [82] \\
\hline & Indica & $B A D H 2$ & $\begin{array}{l}\text { Betaine aldehyde } \\
\text { dehydrogenase } \\
\text { (fragrant rice) }\end{array}$ & OsUbi & OsU6a & Enhanced fragrance & [81] \\
\hline & $\begin{array}{l}\text { Zhonghua } 11 \\
\text { (Japonica) }\end{array}$ & GS9, DEP1 & $\begin{array}{l}\text { Grain size, } \\
\text { Panicle } \\
\text { architecture }\end{array}$ & OsUbi & OsU6a & $\begin{array}{l}\text { Slender grain shape, } \\
\text { less chalkiness }\end{array}$ & [84] \\
\hline & IR-96 & $\begin{array}{c}\text { Cyt P450 } \\
\text { homoeologs, B } \\
\text { OsBADH2 }\end{array}$ & $\begin{array}{l}\text { Grain yield and } \\
\text { fragrance }\end{array}$ & Pubi & $\begin{array}{l}\text { OsU6a, OsU6b, } \\
\text { OsU6c, OsU3m }\end{array}$ & $\begin{array}{l}\text { Increased grain size, } \\
\text { and fragrance }\end{array}$ & [39] \\
\hline \multirow{5}{*}{$\begin{array}{l}\text { Physical and } \\
\text { appearance } \\
\text { quality }\end{array}$} & Indica (VP4892) & OsSPL16/GW8 & Grain size & pUbi & OsU6aOsU6b & Increased grain size & [38] \\
\hline & $\begin{array}{l}\text { Zhonghua-11 } \\
\text { (Japonica) }\end{array}$ & GS3/Gn la, & $\begin{array}{l}\text { Grain } \\
\text { size-3/grain } \\
\text { number la }\end{array}$ & OsUbi & OsU6a & Increased grain length & [31] \\
\hline & Japonica & GS3 & Grain size-3 & $\begin{array}{l}2 \times 35 S \\
\text { Pubi-H }\end{array}$ & OsU6a & Increased grain size & [33] \\
\hline & $\begin{array}{l}\text { Nipponbare } \\
\text { (Japonica) }\end{array}$ & $\begin{array}{l}\text { GW2/GW5/ } \\
\text { TGW6 }\end{array}$ & Grain weight & OsUbi & $\begin{array}{l}\text { OsU3, OsU6, } \\
\text { TaU3 }\end{array}$ & $\begin{array}{l}\text { Increased grain length } \\
\text { and width }\end{array}$ & [36] \\
\hline & Japonica & OsFWL & Grain Length & Maize Ubi1 & OsU6 & Increased grain length & [32] \\
\hline \multirow{4}{*}{$\begin{array}{l}\text { Nutritional } \\
\text { Quality }\end{array}$} & Indica & OsNramp5 & Cd accumulation & ZmUBI & OsU6a & Low $\mathrm{Cd}$ in grains & [87] \\
\hline & $\begin{array}{c}\text { Indica } \\
\text { (Huazhan and } \\
\text { Longke 638S) }\end{array}$ & OsNramp5 & Cd accumulation & Pubi-H & OsU6a & Low $\mathrm{Cd}$ in grains & [86] \\
\hline & Rice Protoplast & $\mathrm{OsOr}$ & $\begin{array}{l}\beta \text {-carotene } \\
\text { synthesis }\end{array}$ & $2 \times 35 S$ & OsU6-2 & $\begin{array}{l}\text { Increased } \beta \text {-carotene } \\
\text { (provitamin A) content }\end{array}$ & [89] \\
\hline & Kitaake & SSU-crtI, ZmPsy & $\begin{array}{l}\beta \text {-carotene } \\
\text { synthesis }\end{array}$ & & & $\begin{array}{l}\text { Increased } \beta \text {-carotene } \\
\text { (provitamin A) content }\end{array}$ & [90] \\
\hline
\end{tabular}

\section{Prime Editing and Cas Variants for Rice Crop Improvement}

PE is a newly developed system utilizing modified Cas9 protein/s and PE guide RNA (pegRNA) that ensures the cut is made in a single strand instead of both DNA strands in a traditional CRSIRP/Cas9 system, and improves the accuracy of genome editing (Figure 2). In rice, 179 predicted off-target sites were targeted by PE i.e., 12 pegRNAs and a Cas9 variant, nCas9 (H840A) but off-target edits (indels) had quite low frequencies of $0.00 \sim 0.23 \%$ [91]. This explains the power of PE system for precise, targeted, and accurate genome editing. The PE system can produce 12 kinds of point mutations, including all six possible base pair conversions, base substitutions, insertions, and deletions in rice protoplast [19] that make it a powerful crop improvement system.

Recent research on PE application in rice has been conducted by constructing prime editors Sp-PE2 and Sp-PE3 using Cas9 variant, SpCas9. An expression cassette comprising pegRNA, ZmUbi promoter, OsU6, and an inactive EGFP driven by CaMV35 promoter was 
inserted into Sp-PE2, and Sp-PE3 was used to observe mutations. Sp-PE2 has a higher efficiency, showing a strong GFP signal as compared to Sp-PE3. These PE were used to edit $A L S$, and BERRANT PANICLE ORGANIZATION 1 (APO1) genes, thus generating stable mutant lines [23]. Similarly, plant prime editor 3 version 1 (PPE3-V01) with engineered (MMLV) RT and Cas9H840A were optimized for its application in rice cells. Five target sites in four rice genes (OsKO2, OsDEP1, OsDPS, OsALS) confirmed the PE activities and found SNPs and indels at variable frequencies [21]. Another PE system (pPE2) was found to be an efficient system for precise genome editing, targeting different genome sites in rice. The pPE2 system performed better than the pPE3 system for different genomic sites. Moreover, a surrogate $\mathrm{pPE} 2$ system in which the hygromycin phosphotransferase (HPT) reporter gene with an ACG substitution at the start codon ( $\mathrm{HPT}^{-\mathrm{ATG}}$ ) was incorporated into prime edited cells, thus easily detecting nucleotide editing, and developed new corridors for flexible editing in rice [92]. Applications of PE systems and Cas protein variants, such as $\mathrm{dCas} 9$ and Cas12a/Cpf1 to improve the genome editing efficiencies, plant growth and development, plant architecture, herbicide resistance, etc., are detailed in Table 5.

Table 5. Examples of application of prime editing and Cas proteins variants for rice crop improvement.

\begin{tabular}{|c|c|c|c|c|c|c|c|}
\hline Systems & Cultivar Used & Gene Name & $\begin{array}{c}\text { Gene } \\
\text { Function }\end{array}$ & Cas9 Promoter & $\begin{array}{l}\text { sgRNA } \\
\text { Promoter }\end{array}$ & Results & Ref. \\
\hline \multirow{2}{*}{ dCas9 } & Zhonghua 11 & $\begin{array}{l}\text { OsGW7 } \\
\text { OsER1 }\end{array}$ & $\begin{array}{c}\text { Grain size and } \\
\text { shape, } \\
\text { ethylene } \\
\text { upregulation }\end{array}$ & CaMV35S & OsU6a & $\begin{array}{l}\text { Multiplex genome } \\
\text { editing }\end{array}$ & [93] \\
\hline & Rice protoplast & $\begin{array}{c}\text { OsSPL14, } \\
\text { OsIPA, OsGRF1 }\end{array}$ & $\begin{array}{l}\text { Senescence, } \\
\text { plant } \\
\text { architecture }\end{array}$ & Ubi & & $\begin{array}{c}\text { Generate larger } \\
\text { deletions }\end{array}$ & [94] \\
\hline $\begin{array}{l}\text { Cas9 with } \\
\text { APOBEC }\end{array}$ & Rice protoplast & $\begin{array}{c}\text { OsAAT } \\
\text { OsNRT1.1B } \\
\text { OsCDC } 48\end{array}$ & $\begin{array}{l}\text { senescence, cell } \\
\text { death }\end{array}$ & Ubi & CaMV & $\begin{array}{l}\text { Generate short and } \\
\text { larger deletions }\end{array}$ & [95] \\
\hline \multirow{3}{*}{$\begin{array}{c}\text { Cas12a/Cpf1 } \\
\text { FnCpf1 and } \\
\text { CRISPR/ } \\
\text { LbCpf1 }\end{array}$} & Nipponbare & $\begin{array}{c}\text { ALS } \\
\text { (Acetolactate } \\
\text { synthase) }\end{array}$ & $\begin{array}{l}\text { Synthesis of } \\
\text { branched chain } \\
\text { amino acids }\end{array}$ & ZmUBI & OsU6 & $\begin{array}{l}\text { Loss of } A L S \text { activity, } \\
\text { plant death }\end{array}$ & [96] \\
\hline & Rice protoplast & $D E P 1$ & $\begin{array}{c}\text { Dense and } \\
\text { erect } \\
\text { Panicle }\end{array}$ & CaMV35S & OsU6 & Scattered panicle & [97] \\
\hline & Rice protoplast & $\begin{array}{l}\text { OsBEL, OsPDS } \\
\text { OsEPSPS } \\
\text { OsBEL OsRLK }\end{array}$ & $\begin{array}{c}\text { Bentazon- } \\
\text { sensitive-lethal, } \\
\text { Phytoene } \\
\text { Desaturase }\end{array}$ & CaMV35S & OsU6 & $\begin{array}{l}\text { Multiplex gene } \\
\text { editing (Albino } \\
\text { phenotype) }\end{array}$ & [98] \\
\hline \multirow{4}{*}{ Prime editors } & Rice protoplast & $\begin{array}{l}\text { OsALS } \\
\text { APO1 }\end{array}$ & $\begin{array}{c}\text { Acetolactate } \\
\text { synthase, } \\
\text { Panicle } \\
\text { organization }\end{array}$ & CaMV35S & OsU6 & $\begin{array}{l}\text { Resistant to } \\
\text { imidazolinone } \\
\text { herbicides }\end{array}$ & [23] \\
\hline & Nipponbare & $\begin{array}{l}\text { OsPDS1 } \\
\text { OsACC1 } \\
\text { OsWx1 }\end{array}$ & $\begin{array}{l}\text { Herbicide } \\
\text { resistance, } \\
\text { amylose }\end{array}$ & $\begin{array}{c}\text { Ubi-1 } \\
\text { CaMV35S }\end{array}$ & OsU3 & $\begin{array}{l}\text { Enhanced herbicide } \\
\text { tolerance }\end{array}$ & [92] \\
\hline & Rice protoplast & $\begin{array}{c}\text { OsALS, OsACC } \\
\text { OsDEP1 }\end{array}$ & $\begin{array}{l}\text { Nitrogen use } \\
\text { efficiency } \\
\text { Herbicide } \\
\text { tolerance }\end{array}$ & $\begin{array}{l}\text { ZmUbi1 } \\
\text { OsUbq }\end{array}$ & $\begin{array}{l}\text { OsU6a } \\
\text { OsU3 }\end{array}$ & $\begin{array}{c}\text { Nucleotide } \\
\text { substitution, } \\
\text { herbicide resistance }\end{array}$ & [20] \\
\hline & Rice protoplast & $\begin{array}{l}\text { OsALS, OsKO2, } \\
\text { OsDEP1, PDS }\end{array}$ & $\begin{array}{c}\text { Panicle } \\
\text { Architecture }\end{array}$ & ZmUbi1 & $\begin{array}{l}\text { OsU6 } \\
\text { OsU3 }\end{array}$ & $\begin{array}{l}\text { Novel prime editing, } \\
\text { dense panicle } \\
\text { architecture }\end{array}$ & [21] \\
\hline
\end{tabular}

\section{Base Editing for Rice Crop Improvement}

$\mathrm{BE}$ is a novel genome editing tool that utilizes CRISPR components to introduce point mutations or single-nucleotide variants (SNVs) in the genome without making DSBs in DNA and without reliance on HDR (Figure 2). Base editors either contain catalytically 
impaired Cas nuclease that cannot make DSBs or proteins that manipulate DNA repair machinery to turn on NHEJ instead of HDR [99]. There are two types of base editors, i.e., cytosine base editors (CBEs) and Adenine base editors (ABEs). The Cas9 variants, such as xCas9, SpCas9, and SaCas9, used in the cassette of CBEs increased the mutation frequency of $C \bullet G$ to T•A up to $80 \%$ in rice [100]. Recent base editors with Cas9 variants (nSpCas9, nCas 9 , SaCas9) improved the editing efficiency of ABEs (A $\bullet T$ to $\mathrm{G} \bullet C$ conversions) in plants, including rice, for several applications in crop improvement $[100,101]$. Increased ABE efficiency in two target genes OSSPL14 and OsSPL17, with improved PAM compatibility in rice, expand its application in other crops [100]. Better performance in rice could be evident using ABE and CBE systems, simultaneously [102]. Generating larger and precise deletions was challenging to achieve, but now has been reported using a cassette of Cas9, uracil-DNA-glucosidase (UDG), and a lyase (apurinic/apyrimidinic site). The generation of APOBEC-Cas9 fusion induced deletion system (AFIDs) [95] resulted in large uniform deletions in rice and wheat protoplast that can be used to determine their regulations and protein domains for crop improvement. BE has been used to improve grain yield, grain quality, and herbicide resistance in rice (Table 6).

Table 6. Applications of base editing for rice crop improvement.

\begin{tabular}{|c|c|c|c|c|c|c|}
\hline Gene Name & Gene Function & Base Editing Tool & PAM & Editing Window (nt) & Target Trait & Ref. \\
\hline $\begin{array}{c}\text { OsCDC48, } \\
\text { OsNRT1.1B } \\
\text { OsSPL14 }\end{array}$ & $\begin{array}{l}\text { senescence, cell death, } \\
\text { plant architecture }\end{array}$ & pnCas9-PBE & CGG & 3 to 9 & Yield & [103] \\
\hline $\begin{array}{l}\text { SPL14, SPL17, } \\
\text { SPL16, } \\
\text { SPL18 }\end{array}$ & $\begin{array}{c}\text { Grain weight, size, } \\
\text { shape, quality, } \\
\text { number }\end{array}$ & $\begin{array}{l}\text { ABE-P1 } \\
\text { ABE-P2 } \\
\text { ABE-P3 } \\
\text { ABE-P4 } \\
\text { ABE-P5 }\end{array}$ & $\begin{array}{c}\text { GAG } \\
\text { CAG } \\
\text { CGA } \\
\text { GGA } \\
\text { AGCG } \\
\text { GGCG }\end{array}$ & 3 to 15 & Yield & [102] \\
\hline $\begin{array}{l}\text { SLR1, SPL14, SPL16, } \\
\text { SPL18, SPL17 }\end{array}$ & $\begin{array}{c}\text { Grain weight, size, } \\
\text { shape, quality, } \\
\text { number }\end{array}$ & $\begin{array}{l}\text { ABE-P1 } \\
\text { ABE-P2 }\end{array}$ & NNGRRT & 4 to 9 & Yield & [17] \\
\hline NRT1.1B & Nitrogen transporter & $\begin{array}{l}\text { APOBEC1-XTEN- } \\
\text { Cas9(D10A) }\end{array}$ & $\begin{array}{l}\text { AGG } \\
\text { GGG }\end{array}$ & 5 & $\begin{array}{l}\text { High nitrogen use } \\
\text { Efficiency }\end{array}$ & [104] \\
\hline SBEIIb & $\begin{array}{c}\text { Starch } \\
\text { branching enzyme }\end{array}$ & CBE & $\mathrm{CCT}$ & 5 & High amylose & [105] \\
\hline Wx or GBSSI & Starch synthesis & CBE & $\begin{array}{l}\text { CCA } \\
\text { CGG }\end{array}$ & 4 & High amylose & [106] \\
\hline OsALS1 & $\mathrm{ABC}$ transporter & BEMGE & $\begin{array}{l}\text { CGG } \\
\text { CAG }\end{array}$ & $5-7$ & $\begin{array}{l}\text { Herbicide } \\
\text { resistance }\end{array}$ & [107] \\
\hline OsALS1 & $\mathrm{ABC}$ transporter & CBE & $\begin{array}{l}\text { CGG } \\
\mathrm{CCT}\end{array}$ & $3-5$ & $\begin{array}{l}\text { Herbicide } \\
\text { resistance }\end{array}$ & [108] \\
\hline OsACC & Herbicide resistance & $\begin{array}{l}\text { eABE } \\
\text { eBE3 }\end{array}$ & TGG & 3 to 9 & $\begin{array}{l}\text { Herbicide } \\
\text { resistance }\end{array}$ & [109] \\
\hline
\end{tabular}

\subsection{Grain Yield and Related Traits}

BE systems, particularly $\mathrm{ABE}$ has been used to introduce point mutations in several Squamosa Promoter Binding Protein-Like genes, such as OsSPL14, SPL16, SPL17, and SPL18 [16,102,103], to target plant architecture, grain weight, size, and shape, in order to improve the yield. Similarly, BE has been used to target nitrate transporter 1, OsNRT1.1B $[103,104]$ to improve the nitrogen use efficiency of rice plants as an indirect strategy to improve the grain yield of rice.

\subsection{Grain Quality}

Some gene/s controlling rice grain quality has been modified through BE. For example, an efficient cytosine base editor 3, CBE3, system was applied to alter three target sequences in two rice genes simultaneously, including two targets in OsBEIIb (starch branching enzyme 
$2 b$ ) named (S3 and S5), and another target site (P2) in rice Phytoene Desaturase (OsPDS). This system resulted in desired precise point mutations having a mutation frequency of $19.2 \%, 10.5 \%$, and $1.0 \%$ at S5, S3, and P2 targets, respectively. The resultant mutations in these genes resulted in high amylose contents in rice [105]. Similarly, transgene-free mutants produced by targeting Wx gene/GBSS1 protein using a cytidine BE system [106] changed the amino acid sequence and altered amylose contents of rice grain.

\subsection{Herbicide Resistance}

$\mathrm{BE}$ systems have been used to improve the herbicide resistance in rice by targeting OsALS and OsACC genes [107-109]. Among these, a novel base-editing-mediated gene evolution based breeding strategy was used to target 3-5 nucleotides of OsALS gene that conferred resistance against bispyribac-sodium herbicide [107]. Similarly, CBE system was used to introduce missense mutation in two codons of OsALS [108]. This novel breeding approach resulted in resistance against five herbicides i.e. bispyribac-sodium, Flucarbazone-sodium, imazapic (IMP), nicosulfuron, and pyroxsulam.

\section{Regulatory Aspects and Risks Associated with Genome Editing}

Genome editing, predominantly CRISPR technology, certainly has a great potential for revolutionizing plant science as it can create genetic variants like that of natural variants. The main concern for these edited crops is their regulation across the world. The legislation and regulatory framework are evolving in different countries; however, we need to know the recent policies in Europe to adopt new technologies [110]. Genome editing is categorized by site-directed nucleases (SDNs), generating variations in the host genome. TALEN or Cas9 targets a specific site generating a DNA break that is impaired by the plant's natural DNA repair mechanism (Figure 2). SDNs resulted in target site variants causing three types of modifications, such as SDN-1, base-pair changes due to small deletions, or insertions with no foreign DNA. SDN-2 causes a specific change due to homologous recombination using a small DNA template, and the SDN-3 approach is just like SDN-2, but uses a larger DNA segment [111]. A plant having a larger segment of foreign DNA is identified as a transgenic plant. Biosafety legislation of such plants is approved by adaptation of SDN-induced variants in many countries [110]. The EU Court of Justice (ECJ) categorized all genome-edited organisms as GMO.

Other than the EU, New Zealand also considers genome edited plants as GMOs and regulates these mutants under GM biosafety rules. Organisms generated through conventional mutagenesis are exempted because of a safe use history record. ECJ had a negative impact on agricultural innovation, as only $8 \%$ of CRISPR patents originate from Europe, while $60 \%$ from China and 26\% from the USA. In October 2019, the European Union demanded to highlight GETS status, which would have been compiled in April 2021. Future application of genome editing, their ethical and societal issues, and a risk assessment framework will be proposed by the European Food Safety Authority (EFSA). Argentina follows regulatory criteria for gene-edited crops as they classified SDN-3 generated crops under GMOs; however, crops modified by SDN-1 as a non-GMO. Crops generated by SDN-2 do not follow any regulatory criteria [112].

Brazil, Chile, and Columbia also follow the same regulatory criteria as in Argentina. If plants do not have any foreign DNA, they will not be regulated as GMOs. Similar to the USA, Canada is also conscious about the 'novelty' of traits for regulatory assessment. Plants propagated by SDN-1 and SDN-2 have to follow the same assessment or regulation established by the Canadian Food Inspection Agency (CFIA) and Health Canada [113]. Japan employs the same rule (if plants do not have any foreign DNA, they will not be regulated as GMOs), thus they are regulated as conventional crops and can be consumed without any safety evaluation, but this suggestion must still be adopted formally by the Ministry of health [114]. In Australia, the Gene Technology Regulations Review was presented with updated amendments. These amendments classified SDN-2 and SDN-3 developed plants as GMOs, and SDN-1 plants as non-GMOs [115], but still need government approval. 
China focuses on processes or techniques used to create new crop varieties and provides huge financial support. No rules for gene-edited crops have been proposed yet but we expect that China will regulate gene-edited crops in a required manner, just like Japan. Recently, France opposed the EU court's decision by not considering GETs under strict GMO biosafety rules. As the largest agricultural producer or the EU, it will consider changing the administrative court's decision on GET regulations (https:/ / www.reuters.com/article/franceagriculture-gmo/france-backs-non-gmo-regulation-for-crop-gene-editing-in-eu-idINL8N2JT4 A3 accessed on 29 June 2021). However, in the present era, scientists should collaborate to harness the potential of CRISPR technology, for example, a joint statement in support of agricultural applications supported by 13 countries, including the United States, Canada, Argentina, Australia, Brazil, Colombia, the Dominican Republic, Guatemala, Honduras, Jordan, Paraguay, Uruguay, and Vietnam. This statement is a good sign for overwhelming differences among countries regarding regulatory frameworks, thus empowering innovative agriculture. Though the CRISPR-Cas system is producing transgenic free plants, GMO regulation is acceptable by the scientific societies of some countries only.

\section{Limitations and Solutions}

GETs have great potential over conventional breeding in developing high-quality rice varieties due to their high efficiency, precision, robustness, and multiplex editing ability. Regardless of GET efficiency (especially the CRISPR-Cas system) and their vast application, they still have some limitations that hamper their usage for crop improvement. Some of these hindrances are:

- Disruption/mutation of the targeted gene may cost some fitness, as it can disturb the pathway of the product or any product or element involved in this pathway. A gene has a linkage with many other genes and regulating pathways. This fitness cost may affect genes regulating plant growth and development, deficiency of essential nutrients leading to visual abnormalities. In order to overcome this limitation, the $\mathrm{BE}$ method is applicable, targeting a single nucleotide mutation, escaping disruption of other genes, or targeting promoter to generate alleles [116].

- "Off-target mutations" is another major limitation and significant support for improving the CRISPR system [117]. Unintended or undesired DNA modifications created by deceptive gRNA or a gRNA- independent method or non-specific sites fall under off-target mutations [118]. Possible solutions to cope with off-target mutations and production of transgene-free crops are improving the CRISPR system for precise and reliable editing, or developing an approach to identify off-target mutation. Some bioinformatics tools have been established that can detect off-targets, i.e., Cas-OFFinder (http:/ / www.rgenome.net/cas-offinder/, accessed on 29 June 2021) and CCTop (https: / / crispr.cos.uniheidelberg.de, accessed on 29 June 2021), and also some systems, such as SELEX, IDLV capture, Guide-seq, HTGTS, BLESS, Digenomeseq [119] and DISCOVER-seq [120]. Still, researchers must use these tools according to the requirements due to their specific pros and cons. In contrast, Cas9 proteins have been modified for improved target specificity, including eSpCas9 [121], HF-Cas9 [122], HypaCas9 [123], and Sniper Cas9 [124]. These engineered Cas proteins had an incredible reduction in off-target activity. Cytosine, instead of adenine, is responsible for an off-target mutation in rice hence needs further improvement in tools like base editors [118]. Moreover, PE is also a reliable tool for reducing off-target mutations e.g., targeting of 179 predicted off-target sites with 12 pegRNAs and nCas9 nickase [91] resulted in $0.00 \sim 0.23 \%$ of off-target mutations.

- Another limiting factor is the commercial adaptation of genome-edited crops in some countries and has been discussed in detail earlier (see regulatory aspects and risks associated with genome editing). Although the GM crop decision and utilization of GETs is pending, there is great potential for robust, efficient, and environmentally friendly breeding for improved variety development. 
- Immune DNA/RNA viruses towards eukaryotes is a crucial limitation of the CRISPR/ Cas9 system due to outflow and instant replication of viruses [125]. There is a dire need for a widely acceptable CRISPR version, such as Cas13, to overwhelm this issue. Among all three proteins (Cas13a, Cas13b, and Cas13c), Cas13a is referred for its precise, robust RNA replications, and can exert against RNA viruses [126]. In short, Cas13 would be a better choice for targeting viral RNA against CRISPR/Cas9.

- In case of BE, many obstacles, such as high off-target activity, huge editing window, and limited PAM sites limit its efficiency. Several approaches have been used to minimize these limitations, including application of the REPAIR and RESCUE system in plants, alteration of the $\mathrm{CBE}$ and $\mathrm{ABE}$ system, generating mutations simultaneously at multiple loci in rice [116], such as multiplex BE for crop improvement. RNP approach had also overcome the regulatory obstacles of base editors by increased efficiency to improve agronomic traits.

- PE also exhibits some key issues, including cell type determinants, state of cell, DNA repair mechanisms deciding the fate of productive or unproductive PE or transport of PE protein or pegRNA for regulation of in vivo applications. This issue could be resolved by manipulating DNA repair favoring to replace the edited strand over the non-edited strand subsequent to successful insertion of a $3^{\prime}$ flap, or alternatively use smaller reverse transcriptase enzymes.

\section{Conclusions and Outlook}

Significant advancements have been made in genome editing tools, especially the CRISPR-Cas system and its variants. These new GETs have made crop improvement precise, robust, and better than earlier methods (i.e., conventional breeding). Owing to multiple genome editing skills, i.e., insertion, deletions, gene knockout/in, direct substitution at any loci, the CRISPR/Cas system is ruling over the other GETs for the development of ideal plants and crop domestication, i.e., super rice generation. CRISPR/Cas system has been used to develop a variety with desired changes and phenotypes in already existing elite rice varieties, consequently enhanced rice grain quality. Developing versatile approaches, such as CRISPR-based BE, PE, CRISPR transposes, and recombinases would provide exciting opportunities in genome editing. They also highlight a major milestone enabling precise sequence alteration of any desired genome as well as rearrangements of larger DNA sequences. Editing efficiency of PE can be enhanced by using a different transgenic selection system and reverse transcriptase.

The new addition of CRISPR-interference (CRISPRi) and CRISPR-mediated activation (CRISPRa) in the CRISPR family, using the dCas9 toolkit, as developed in maize [127], has great potential for further improvement of genome engineering. Targeting the core promoter of a gene by editing technologies could be a reliable approach for fine-tuning of any desired gene expression, unearthing new avenues for breeding improved rice grain quality. Moreover, novel and potential delivery methods used in the latest approaches for gene editing will produce transgene-free products; hence, overcoming the limitation of ethical, regulatory, and commercialization issues. Utilization of these editing technologies in functional genomics linked with other approaches will allow combating global food challenges and will help to accomplish the zero-hunger goal, one of the sustainable development goals set by the United Nations, by 2030.

On the other hand, it is reported that an autophagy gene OsATG8b controls grain quality in addition to candidate genes, including $q G C 10$ for gel consistency, $q H d 2-1$ and qGS-7 for grain size, physical appearance of grain, eating, and cooking quality [128-130]. Similarly, several novel QTL, metaQTL, ortho-MQTL, and candidate genes for grain yield and related traits, drought, salinity, and heat stresses have been identified [131-133]. Employing the latest editing technologies on these candidate genes/QTLs has remarkable potential for fine-tuning rice grain yield, abiotic stress tolerance, grain appearance, and quality improvement in the future breeding program. 
Author Contributions: Conceptualization, L.J., S.A., and B.H.; resources and data curation, A.M.M. and A.Z.; writing-original draft preparation, J.T. and S.A.; writing-review and editing, S.A. and B.H.; visualization, S.A.; supervision, L.J. and S.A.; funding acquisition, L.J. All authors have read and agreed to the published version of the manuscript.

Funding: This work was supported by grants from the National Major Science and Technology Program on New GMO Organism Variety Breeding (2016ZX08001-001), Central Public-interest Scientific Institution Basal Research Fund (No. 2017RG008) and Agricultural Sciences and Technologies Innovation Program of Chinese Academy of Agricultural Sciences (CAAS).

Institutional Review Board Statement: Not applicable.

Informed Consent Statement: Not applicable.

Data Availability Statement: Not applicable.

Acknowledgments: We apologize to colleagues whose work was not cited in this review owing to space limitations.

Conflicts of Interest: The authors declare no conflict of interest.

\section{References}

1. Zhang, Q.; Chen, Q.; Wang, S.; Hong, Y.; Wang, Z. Rice and cold stress: Methods for its evaluation and summary of cold tolerance-related quantitative trait loci. Rice 2014, 7, 24. [CrossRef] [PubMed]

2. Zhao, M.; Lin, Y.; Chen, H. Improving nutritional quality of rice for human health. Theor. Appl. Genet. 2020, 133, 1397-1413. [CrossRef]

3. Ray, D.K.; Mueller, N.D.; West, P.C.; Foley, J.A. Yield Trends Are Insufficient to Double Global Crop Production by 2050. PLoS ONE 2013, 8, e66428. [CrossRef]

4. Budak, H.; Hussain, B.; Khan, Z.; Ozturk, N.Z.; Ullah, N. From genetics to functional genomics: Improvement in drought signaling and tolerance in wheat. Front. Plant Sci. 2015, 6, 1-13. [CrossRef]

5. Oladosu, Y.; Rafii, M.Y.; Samuel, C.; Fatai, A.; Magaji, U.; Kareem, I.; Kamarudin, Z.S.; Muhammad, I.; Kolapo, K. Drought Resistance in Rice from Conventional to Molecular Breeding: A Review. Int. J. Mol. Sci. 2019, 20, 3519. [CrossRef]

6. Ma, N.L.; Che Lah, W.A.; Abd. Kadir, N.; Mustaqim, M.; Rahmat, Z.; Ahmad, A.; Lam, S.D.; Ismail, M.R. Susceptibility and tolerance of rice crop to salt threat: Physiological and metabolic inspections. PLoS ONE 2018, 13, e0192732. [CrossRef] [PubMed]

7. Hsu, P.D.; Lander, E.S.; Zhang, F. Development and Applications of CRISPR-Cas9 for Genome Engineering. Cell 2014, 157, 1262-1278. [CrossRef] [PubMed]

8. Jiang, Y.; Cai, Z.; Xie, W.; Long, T.; Yu, H.; Zhang, Q. Rice functional genomics research: Progress and implications for crop genetic improvement. Biotechnol. Adv. 2012, 30, 1059-1070. [CrossRef] [PubMed]

9. Kim, H.J.; Lee, H.J.; Kim, H.; Cho, S.W.; Kim, J.-S. Targeted genome editing in human cells with zinc finger nucleases constructed via modular assembly. Genome Res. 2009, 19, 1279-1288. [CrossRef] [PubMed]

10. Cebrian-Serrano, A.; Davies, B. CRISPR-Cas orthologues and variants: Optimizing the repertoire, specificity and delivery of genome engineering tools. Mamm. Genome 2017, 28, 247-261. [CrossRef] [PubMed]

11. Naeem, M.; Majeed, S.; Hoque, M.Z.; Ahmad, I. Latest Developed Strategies to Minimize the Off-Target Effects in CRISPR-CasMediated Genome Editing. Cells 2020, 9, 1608. [CrossRef]

12. Hussain, B.; Lucas, S.J.; Budak, H. CRISPR/Cas9 in plants: At play in the genome and at work for crop improvement. Brief. Funct. Genom. 2018, 17, 319-328. [CrossRef]

13. Adli, M. The CRISPR tool kit for genome editing and beyond. Nat. Commun. 2018, 9, 1911. [CrossRef]

14. Zhang, Y.; Massel, K.; Godwin, I.D.; Gao, C. Applications and potential of genome editing in crop improvement. Genome Biol. 2018, 19, 210. [CrossRef] [PubMed]

15. Komor, A.C.; Kim, Y.B.; Packer, M.S.; Zuris, J.A.; Liu, D.R. Programmable editing of a target base in genomic DNA without double-stranded DNA cleavage. Nature 2016, 533, 420-424. [CrossRef] [PubMed]

16. Hua, K.; Tao, X.; Yuan, F.; Wang, D.; Zhu, J.-K. Precise A·T to G.C Base Editing in the Rice Genome. Mol. Plant 2018, 11, 627-630. [CrossRef]

17. Hua, K.; Tao, X.; Liang, W.; Zhang, Z.; Gou, R.; Zhu, J. Simplified adenine base editors improve adenine base editing efficiency in rice. Plant Biotechnol. J. 2020, 18, 770-778. [CrossRef] [PubMed]

18. Shimatani, Z.; Kashojiya, S.; Takayama, M.; Terada, R.; Arazoe, T.; Ishii, H.; Teramura, H.; Yamamoto, T.; Komatsu, H.; Miura, K.; et al. Targeted base editing in rice and tomato using a CRISPR-Cas9 cytidine deaminase fusion. Nat. Biotechnol. 2017, 35, 441-443. [CrossRef] [PubMed]

19. Lin, Q.; Zong, Y.; Xue, C.; Wang, S.; Jin, S.; Zhu, Z.; Wang, Y.; Anzalone, A.V.; Raguram, A.; Doman, J.L.; et al. Prime genome editing in rice and wheat. Nat. Biotechnol. 2020, 38, 582-585. [CrossRef]

20. Xu, W.; Zhang, C.; Yang, Y.; Zhao, S.; Kang, G.; He, X.; Song, J.; Yang, J. Versatile Nucleotides Substitution in Plant Using an Improved Prime Editing System. Mol. Plant 2020, 13, 675-678. [CrossRef] 
21. Tang, X.; Sretenovic, S.; Ren, Q.; Jia, X.; Li, M.; Fan, T.; Yin, D.; Xiang, S.; Guo, Y.; Liu, L.; et al. Plant Prime Editors Enable Precise Gene Editing in Rice Cells. Mol. Plant 2020, 13, 667-670. [CrossRef]

22. Li, H.; Li, J.; Chen, J.; Yan, L.; Xia, L. Precise Modifications of Both Exogenous and Endogenous Genes in Rice by Prime Editing. Mol. Plant 2020, 13, 671-674. [CrossRef]

23. Hua, K.; Jiang, Y.; Tao, X.; Zhu, J. Precision genome engineering in rice using prime editing system. Plant Biotechnol. J. 2020, 18, 2167-2169. [CrossRef]

24. Hussain, B. Modernization in plant breeding approaches for improving biotic stress resistance in crop plants. Turkish J. Agric. For. 2015, 39, 515-530. [CrossRef]

25. Jiao, Y.; Wang, Y.; Xue, D.; Wang, J.; Yan, M.; Liu, G.; Dong, G.; Zeng, D.; Lu, Z.; Zhu, X.; et al. Regulation of OsSPL14 by OsmiR156 defines ideal plant architecture in rice. Nat. Genet. 2010, 42, 541-544. [CrossRef] [PubMed]

26. Okada, S.; Sasaki, M.; Yamasaki, M. A novel Rice QTL qOPW11 Associated with Panicle Weight Affects Panicle and Plant Architecture. Rice 2018, 11, 53. [CrossRef]

27. Zhao, L.; Tan, L.; Zhu, Z.; Xiao, L.; Xie, D.; Sun, C. PAY 1 improves plant architecture and enhances grain yield in rice. Plant J. 2015, 83, 528-536. [CrossRef]

28. Hu, X.; Cui, Y.; Dong, G.; Feng, A.; Wang, D.; Zhao, C.; Zhang, Y.; Hu, J.; Zeng, D.; Guo, L.; et al. Using CRISPR-Cas9 to generate semi-dwarf rice lines in elite landraces. Sci. Rep. 2019, 9, 19096. [CrossRef]

29. Cui, Y.; Hu, X.; Liang, G.; Feng, A.; Wang, F.; Ruan, S.; Dong, G.; Shen, L.; Zhang, B.; Chen, D.; et al. Production of novel beneficial alleles of a rice yield-related QTL by CRISPR/Cas9. Plant Biotechnol. J. 2020, 18, 1987-1989. [CrossRef]

30. Han, Y.; Teng, K.; Nawaz, G.; Feng, X.; Usman, B.; Wang, X.; Luo, L.; Zhao, N.; Liu, Y.; Li, R. Generation of semi-dwarf rice (Oryza sativa L.) lines by CRISPR/Cas9-directed mutagenesis of OsGA20ox2 and proteomic analysis of unveiled changes caused by mutations. 3 Biotech 2019, 9, 387. [CrossRef] [PubMed]

31. Li, M.; Li, X.; Zhou, Z.; Wu, P.; Fang, M.; Pan, X.; Lin, Q.; Luo, W.; Wu, G.; Li, H. Reassessment of the Four Yield-related Genes Gn1a, DEP1, GS3, and IPA1 in Rice Using a CRISPR/Cas9 System. Front. Plant Sci. 2016, 7, 377. [CrossRef]

32. Gao, Q.; Li, G.; Sun, H.; Xu, M.; Wang, H.; Ji, J.; Wang, D.; Yuan, C.; Zhao, X. Targeted Mutagenesis of the Rice FW 2.2-Like Gene Family Using the CRISPR/Cas9 System Reveals OsFWL4 as a Regulator of Tiller Number and Plant Yield in Rice. Int. J. Mol. Sci. 2020, 21, 809. [CrossRef]

33. Zeng, Y.; Wen, J.; Zhao, W.; Wang, Q.; Huang, W. Rational Improvement of Rice Yield and Cold Tolerance by Editing the Three Genes OsPIN5b, GS3, and OsMYB30 With the CRISPR-Cas9 System. Front. Plant Sci. 2020, 10. [CrossRef]

34. Huang, L.; Zhang, R.; Huang, G.; Li, Y.; Melaku, G.; Zhang, S.; Chen, H.; Zhao, Y.; Zhang, J.; Zhang, Y.; et al. Developing superior alleles of yield genes in rice by artificial mutagenesis using the CRISPR/Cas9 system. Crop J. 2018, 6, 475-481. [CrossRef]

35. Shen, L.; Wang, C.; Fu, Y.; Wang, J.; Liu, Q.; Zhang, X.; Yan, C.; Qian, Q.; Wang, K. QTL editing confers opposing yield performance in different rice varieties. J. Integr. Plant Biol. 2018, 60, 89-93. [CrossRef] [PubMed]

36. Xu, R.; Yang, Y.; Qin, R.; Li, H.; Qiu, C.; Li, L.; Wei, P.; Yang, J. Rapid improvement of grain weight via highly efficient CRISPR/Cas9-mediated multiplex genome editing in rice. J. Genet. Genom. 2016, 43, 529-532. [CrossRef]

37. Zhou, J.; Xin, X.; He, Y.; Chen, H.; Li, Q.; Tang, X.; Zhong, Z.; Deng, K.; Zheng, X.; Akher, S.A.; et al. Multiplex QTL editing of grain-related genes improves yield in elite rice varieties. Plant Cell Rep. 2019, 38, 475-485. [CrossRef] [PubMed]

38. Usman, B.; Nawaz, G.; Zhao, N.; Liao, S.; Qin, B.; Liu, F.; Liu, Y.; Li, R. Programmed editing of rice (Oryza sativa 1.) osspl16 gene using crispr/cas9 improves grain yield by modulating the expression of pyruvate enzymes and cell cycle proteins. Int. J. Mol. Sci. 2021, 22, 249. [CrossRef]

39. Usman, B.; Nawaz, G.; Zhao, N.; Liu, Y.; Li, R. Generation of High Yielding and Fragrant Rice (Oryza sativa L.) Lines by CRISPR/Cas9 Targeted Mutagenesis of Three Homoeologs of Cytochrome P450 Gene Family and OsBADH2 and Transcriptome and Proteome Profiling of Revealed Changes Triggered by Mutations. Plants 2020, 9, 788. [CrossRef] [PubMed]

40. Usman, B.; Nawaz, G.; Zhao, N.; Liao, S.; Liu, Y.; Li, R. Precise Editing of the OsPYL9 Gene by RNA-Guided Cas9 Nuclease Confers Enhanced Drought Tolerance and Grain Yield in Rice (Oryza sativa L.) by Regulating Circadian Rhythm and Abiotic Stress Responsive Proteins. Int. J. Mol. Sci. 2020, 21, 7854. [CrossRef]

41. Miao, C.; Xiao, L.; Hua, K.; Zou, C.; Zhao, Y.; Bressan, R.A.; Zhu, J.-K. Mutations in a subfamily of abscisic acid receptor genes promote rice growth and productivity. Proc. Natl. Acad. Sci. USA 2018, 115, 6058-6063. [CrossRef] [PubMed]

42. Hussain, B.; KHAN, A.S.; Ali, Z. Genetic variation in wheat germplasm for salinity tolerance at seedling stage: Improved statistical inference. Turkish J. Agric. For. 2015, 39, 182-192. [CrossRef]

43. Hussain, B.; Lucas, S.J.; Ozturk, L.; Budak, H. Mapping QTLs conferring salt tolerance and micronutrient concentrations at seedling stagein wheat. Sci. Rep. 2017, 7, 15662. [CrossRef]

44. Ahmad, S.; Sheng, Z.; Jalal, R.S.; Tabassum, J.; Ahmed, F.K.; Hu, S.; Shao, G.; Wei, X.; Abd-Elsalam, K.A.; Hu, P.; et al. CRISPR-Cas technology towards improvement of abiotic stress tolerance in plants. In CRISPR and RNAi Systems; Elsevier: Amsterdam, The Netherlands, 2021; pp. 755-772.

45. Lou, D.; Wang, H.; Liang, G.; Yu, D. OsSAPK2 Confers Abscisic Acid Sensitivity and Tolerance to Drought Stress in Rice. Front. Plant Sci. 2017, 8, 1-15. [CrossRef] [PubMed]

46. Ogata, T.; Ishizaki, T.; Fujita, M.; Fujita, Y. CRISPR/Cas9-targeted mutagenesis of OsERA1 confers enhanced responses to abscisic acid and drought stress and increased primary root growth under nonstressed conditions in rice. PLoS ONE 2020, 15, e0243376. [CrossRef] 
47. Liao, S.; Qin, X.; Luo, L.; Han, Y.; Wang, X.; Usman, B.; Nawaz, G.; Zhao, N.; Liu, Y.; Li, R. CRISPR/Cas9-Induced Mutagenesis of Semi-Rolled Leaf1,2 Confers Curled Leaf Phenotype and Drought Tolerance by Influencing Protein Expression Patterns and ROS Scavenging in Rice (Oryza sativa L.). Agronomy 2019, 9, 728. [CrossRef]

48. Shahzad, R.; Jamil, S.; Ahmad, S.; Nisar, A.; Amina, Z.; Saleem, S.; Zaffar Iqbal, M.; Muhammad Atif, R.; Wang, X. Harnessing the potential of plant transcription factors in developing climate resilient crops to improve global food security: Current and future perspectives. Saudi J. Biol. Sci. 2021, 28, 2323-2341. [CrossRef]

49. Santosh Kumar, V.V.; Verma, R.K.; Yadav, S.K.; Yadav, P.; Watts, A.; Rao, M.V.; Chinnusamy, V. CRISPR-Cas9 mediated genome editing of drought and salt tolerance (OsDST) gene in indica mega rice cultivar MTU1010. Physiol. Mol. Biol. Plants 2020, 26, 1099-1110. [CrossRef]

50. Yue, E.; Cao, H.; Liu, B. OsmiR535, a Potential Genetic Editing Target for Drought and Salinity Stress Tolerance in Oryza sativa. Plants 2020, 9, 1337. [CrossRef]

51. Zhang, A.; Liu, Y.; Wang, F.; Li, T.; Chen, Z.; Kong, D.; Bi, J.; Zhang, F.; Luo, X.; Wang, J.; et al. Enhanced rice salinity tolerance via CRISPR/Cas9-targeted mutagenesis of the OsRR22 gene. Mol. Breed. 2019, 39, 47. [CrossRef]

52. Shen, C.; Que, Z.; Xia, Y.; Tang, N.; Li, D.; He, R.; Cao, M. Knock out of the annexin gene OsAnn3 via CRISPR/Cas9-mediated genome editing decreased cold tolerance in rice. J. Plant Biol. 2017, 60, 539-547. [CrossRef]

53. Asibi, A.E.; Chai, Q.; Coulter, J.A. Rice Blast: A Disease with Implications for Global Food Security. Agronomy 2019,9 , 451. [CrossRef]

54. Pandolfi, V.; Neto, J.; Silva, M.; Amorim, L.; Wanderley-Nogueira, A.; Silva, R.; Kido, E.; Crovella, S.; Iseppon, A. Resistance (R) Genes: Applications and Prospects for Plant Biotechnology and Breeding. Curr. Protein Pept. Sci. 2017, 18, 323-334. [CrossRef]

55. Hussain, B.; Akpınar, B.A.; Alaux, M.; Algharib, A.M.; Sehgal, D.; Ali, Z.; Appels7, R.; Aradottir, G.I.; Batley, J.; Bellec, A.; et al. Wheat genomics and breeding: Bridging the gap. Agrirxiv 2021, 1-57. [CrossRef]

56. Oliva, R.; Ji, C.; Atienza-Grande, G.; Huguet-Tapia, J.C.; Perez-Quintero, A.; Li, T.; Eom, J.-S.; Li, C.; Nguyen, H.; Liu, B.; et al. Broad-spectrum resistance to bacterial blight in rice using genome editing. Nat. Biotechnol. 2019, 37, 1344-1350. [CrossRef]

57. Xu, Z.; Xu, X.; Gong, Q.; Li, Z.; Li, Y.; Wang, S.; Yang, Y.; Ma, W.; Liu, L.; Zhu, B.; et al. Engineering Broad-Spectrum Bacterial Blight Resistance by Simultaneously Disrupting Variable TALE-Binding Elements of Multiple Susceptibility Genes in Rice. Mol. Plant 2019, 12, 1434-1446. [CrossRef]

58. Zeng, X.; Luo, Y.; Vu, N.T.Q.; Shen, S.; Xia, K.; Zhang, M. CRISPR/Cas9-mediated mutation of OsSWEET14 in rice cv. Zhonghua11 confers resistance to Xanthomonas oryzae pv. oryzae without yield penalty. BMC Plant Biol. 2020, 20, 313. [CrossRef] [PubMed]

59. Zafar, K.; Khan, M.Z.; Amin, I.; Mukhtar, Z.; Yasmin, S.; Arif, M.; Ejaz, K.; Mansoor, S. Precise CRISPR-Cas9 Mediated Genome Editing in Super Basmati Rice for Resistance Against Bacterial Blight by Targeting the Major Susceptibility Gene. Front. Plant Sci. 2020, 11. [CrossRef] [PubMed]

60. Ahmad, S.; Wei, X.; Sheng, Z.; Hu, P.; Tang, S. CRISPR/Cas9 for development of disease resistance in plants: Recent progress, limitations and future prospects. Brief. Funct. Genom. 2020, 19, 26-39. [CrossRef] [PubMed]

61. Wang, F.; Wang, C.; Liu, P.; Lei, C.; Hao, W.; Gao, Y.; Liu, Y.G.; Zhao, K. Enhanced rice blast resistance by CRISPR/ Cas9-Targeted mutagenesis of the ERF transcription factor gene OsERF922. PLoS ONE 2016, 11, e0154027. [CrossRef]

62. Foster, A.J.; Martin-Urdiroz, M.; Yan, X.; Wright, H.S.; Soanes, D.M.; Talbot, N.J. CRISPR-Cas9 ribonucleoprotein-mediated co-editing and counterselection in the rice blast fungus. Sci. Rep. 2018, 8, 14355. [CrossRef]

63. Li, S.; Shen, L.; Hu, P.; Liu, Q.; Zhu, X.; Qian, Q.; Wang, K.; Wang, Y. Developing disease-resistant thermosensitive male sterile rice by multiplex gene editing. J. Integr. Plant Biol. 2019, 61, 1201-1205. [CrossRef] [PubMed]

64. Nawaz, G.; Usman, B.; Peng, H.; Zhao, N.; Yuan, R.; Liu, Y.; Li, R. Knockout of Pi21 by CRISPR/Cas9 and iTRAQ-Based Proteomic Analysis of Mutants Revealed New Insights into M. oryzae Resistance in Elite Rice Line. Genes (Basel) 2020, 11, 735. [CrossRef] [PubMed]

65. Kim, Y.-A.; Moon, H.; Park, C.-J. CRISPR/Cas9-targeted mutagenesis of Os8N3 in rice to confer resistance to Xanthomonas oryzae pv. oryzae. Rice 2019, 12, 67. [CrossRef] [PubMed]

66. Macovei, A.; Sevilla, N.R.; Cantos, C.; Jonson, G.B.; Slamet-Loedin, I.; Čermák, T.; Voytas, D.F.; Choi, I.-R.; Chadha-Mohanty, P. Novel alleles of rice eIF4G generated by CRISPR/Cas9-targeted mutagenesis confer resistance to Rice tungro spherical virus. Plant Biotechnol. J. 2018, 16, 1918-1927. [CrossRef] [PubMed]

67. Jiang, W.; Zhou, H.; Bi, H.; Fromm, M.; Yang, B.; Weeks, D.P. Demonstration of CRISPR/Cas9/sgRNA-mediated targeted gene modification in Arabidopsis, tobacco, sorghum and rice. Nucleic Acids Res. 2013, 41, e188. [CrossRef]

68. Li, C.; Li, W.; Zhou, Z.; Chen, H.; Xie, C.; Lin, Y. A new rice breeding method: CRISPR/Cas9 system editing of the Xa13 promoter to cultivate transgene-free bacterial blight-resistant rice. Plant Biotechnol. J. 2020, 18, 313-315. [CrossRef]

69. Sang, Y.; Mejuto, J.-C.; Xiao, J.; Simal-Gandara, J. Assessment of Glyphosate Impact on the Agrofood Ecosystem. Plants 2021, 10, 405. [CrossRef]

70. Hussain, B.; Mahmood, S. Development of transgenic cotton for combating biotic and abiotic stresses. In Cotton Production and Uses: Agronomy, Crop Protection, and Postharvest Technologies; Springer: Singapore, 2020; pp. 527-545. ISBN 9789811514722.

71. Li, J.; Meng, X.; Zong, Y.; Chen, K.; Zhang, H.; Liu, J.; Li, J.; Gao, C. Gene replacements and insertions in rice by intron targeting using CRISPR-Cas9. Nat. Plants 2016, 2, 16139. [CrossRef]

72. Sun, Y.; Zhang, X.; Wu, C.; He, Y.; Ma, Y.; Hou, H.; Guo, X.; Du, W.; Zhao, Y.; Xia, L. Engineering Herbicide-Resistant Rice Plants through CRISPR/Cas9-Mediated Homologous Recombination of Acetolactate Synthase. Mol. Plant 2016, 9, 628-631. [CrossRef] 
73. Wang, F.; Xu, Y.; Li, W.; Chen, Z.; Wang, J.; Fan, F.; Tao, Y.; Jiang, Y.; Zhu, Q.-H.; Yang, J. Creating a novel herbicide-tolerance OsALS allele using CRISPR/Cas9-mediated gene editing. Crop J. 2021, 9, 305-312. [CrossRef]

74. Fiaz, S.; Ahmad, S.; Noor, M.; Wang, X.; Younas, A.; Riaz, A.; Riaz, A.; Ali, F. Applications of the CRISPR/Cas9 System for Rice Grain Quality Improvement: Perspectives and Opportunities. Int. J. Mol. Sci. 2019, 20, 888. [CrossRef]

75. Zhang, G.; Cheng, Z.; Zhang, X.; Guo, X.; Su, N.; Jiang, L.; Mao, L.; Wan, J. Double repression of soluble starch synthase genes SSIIa and SSIIIa in rice (Oryza sativa L.) uncovers interactive effects on the physicochemical properties of starch. Genome 2011, 54, 448-459. [CrossRef] [PubMed]

76. Wambugu, P.; Ndjiondjop, M.-N.; Furtado, A.; Henry, R. Sequencing of bulks of segregants allows dissection of genetic control of amylose content in rice. Plant Biotechnol. J. 2018, 16, 100-110. [CrossRef] [PubMed]

77. Zhang, J.; Zhang, H.; Botella, J.R.; Zhu, J.-K. Generation of new glutinous rice by CRISPR/Cas9-targeted mutagenesis of the Waxy gene in elite rice varieties. J. Integr. Plant Biol. 2018, 60, 369-375. [CrossRef] [PubMed]

78. Huang, L.; Li, Q.; Zhang, C.; Chu, R.; Gu, Z.; Tan, H.; Zhao, D.; Fan, X.; Liu, Q. Creating novel Wx alleles with fine-tuned amylose levels and improved grain quality in rice by promoter editing using CRISPR/Cas9 system. Plant Biotechnol. J. 2020, 18, 2164-2166. [CrossRef] [PubMed]

79. Wang, S.; Yang, Y.; Guo, M.; Zhong, C.; Yan, C.; Sun, S. Targeted mutagenesis of amino acid transporter genes for rice quality improvement using the CRISPR/Cas9 system. Crop J. 2020, 8, 457-464. [CrossRef]

80. Sun, Y.; Jiao, G.; Liu, Z.; Zhang, X.; Li, J.; Guo, X.; Du, W.; Du, J.; Francis, F.; Zhao, Y.; et al. Generation of High-Amylose Rice through CRISPR/Cas9-Mediated Targeted Mutagenesis of Starch Branching Enzymes. Front. Plant Sci. 2017, 8, 1-15. [CrossRef]

81. Ashokkumar, S.; Jaganathan, D.; Ramanathan, V.; Rahman, H.; Palaniswamy, R.; Kambale, R.; Muthurajan, R. Creation of novel alleles of fragrance gene OsBADH2 in rice through CRISPR/Cas9 mediated gene editing. PLoS ONE 2020, 15, e0237018. [CrossRef]

82. Shufen, C.; Yicong, C.; Baobing, F.; Guiai, J.; Zhonghua, S.; Ju, L.; Shaoqing, T.; Jianlong, W.; Peisong, H.; Xiangjin, W. Editing of Rice Isoamylase Gene ISA1 Provides Insights into Its Function in Starch Formation. Rice Sci. 2019, 26, 77-87. [CrossRef]

83. Li, Y.; Fan, C.; Xing, Y.; Yun, P.; Luo, L.; Yan, B.; Peng, B.; Xie, W.; Wang, G.; Li, X.; et al. Chalk5 encodes a vacuolar H+-translocating pyrophosphatase influencing grain chalkiness in rice. Nat. Genet. 2014, 46, 398-404. [CrossRef]

84. Zhao, D.-S.; Li, Q.-F.; Zhang, C.-Q.; Zhang, C.; Yang, Q.-Q.; Pan, L.-X.; Ren, X.-Y.; Lu, J.; Gu, M.-H.; Liu, Q.-Q. GS9 acts as a transcriptional activator to regulate rice grain shape and appearance quality. Nat. Commun. 2018, 9, 1240. [CrossRef]

85. Liu, J.; Wu, X.; Yao, X.; Yu, R.; Larkin, P.J.; Liu, C.-M. Mutations in the DNA demethylase OsROS1 result in a thickened aleurone and improved nutritional value in rice grains. Proc. Natl. Acad. Sci. USA 2018, 115, 11327-11332. [CrossRef] [PubMed]

86. Tang, L.; Mao, B.; Li, Y.; Lv, Q.; Zhang, L.; Chen, C.; He, H.; Wang, W.; Zeng, X.; Shao, Y.; et al. Knockout of OsNramp5 using the CRISPR/Cas9 system produces low Cd-accumulating indica rice without compromising yield. Sci. Rep. 2017, 7, 14438. [CrossRef] [PubMed]

87. Chang, J.-D.; Huang, S.; Konishi, N.; Wang, P.; Chen, J.; Huang, X.-Y.; Ma, J.F.; Zhao, F.-J. Overexpression of the manganese/cadmium transporter OsNRAMP5 reduces cadmium accumulation in rice grain. J. Exp. Bot. 2020, 71, 5705-5715. [CrossRef] [PubMed]

88. Jiang, M.; Liu, Y.; Liu, Y.; Tan, Y.; Huang, J.; Shu, Q. Mutation of Inositol 1,3,4-trisphosphate 5/6-kinase6 Impairs Plant Growth and Phytic Acid Synthesis in Rice. Plants 2019, 8, 114. [CrossRef] [PubMed]

89. Endo, A.; Saika, H.; Takemura, M.; Misawa, N.; Toki, S. A novel approach to carotenoid accumulation in rice callus by mimicking the cauliflower Orange mutation via genome editing. Rice 2019, 12, 81. [CrossRef] [PubMed]

90. Dong, O.X.; Yu, S.; Jain, R.; Zhang, N.; Duong, P.Q.; Butler, C.; Li, Y.; Lipzen, A.; Martin, J.A.; Barry, K.W.; et al. Marker-free carotenoid-enriched rice generated through targeted gene insertion using CRISPR-Cas9. Nat. Commun. 2020, 11, 1178. [CrossRef]

91. Jin, S.; Lin, Q.; Luo, Y.; Zhu, Z.; Liu, G.; Li, Y.; Chen, K.; Qiu, J.-L.; Gao, C. Genome-wide specificity of prime editors in plants. Nat. Biotechnol. 2021. [CrossRef] [PubMed]

92. Xu, R.; Li, J.; Liu, X.; Shan, T.; Qin, R.; Wei, P. Development of Plant Prime-Editing Systems for Precise Genome Editing. Plant Commun. 2020, 1, 100043. [CrossRef] [PubMed]

93. Xiong, X.; Liang, J.; Li, Z.; Gong, B.; Li, J. Multiplex and optimization of dCas9-TV-mediated gene activation in plants. J. Integr. Plant Biol. 2021, 63, 634-645. [CrossRef]

94. Lowder, L.G.; Zhou, J.; Zhang, Y.; Malzahn, A.; Zhong, Z.; Hsieh, T.-F.; Voytas, D.F.; Zhang, Y.; Qi, Y. Robust Transcriptional Activation in Plants Using Multiplexed CRISPR-Act2.0 and mTALE-Act Systems. Mol. Plant 2018, 11, 245-256. [CrossRef]

95. Wang, S.; Zong, Y.; Lin, Q.; Zhang, H.; Chai, Z.; Zhang, D.; Chen, K.; Qiu, J.-L.; Gao, C. Precise, predictable multi-nucleotide deletions in rice and wheat using APOBEC-Cas9. Nat. Biotechnol. 2020, 38, 1460-1465. [CrossRef]

96. Endo, A.; Masafumi, M.; Kaya, H.; Toki, S. Efficient targeted mutagenesis of rice and tobacco genomes using Cpf1 from Francisella novicida. Sci. Rep. 2016, 6, 38169. [CrossRef] [PubMed]

97. Zhong, Z.; Zhang, Y.; You, Q.; Tang, X.; Ren, Q.; Liu, S.; Yang, L.; Wang, Y.; Liu, X.; Liu, B.; et al. Plant Genome Editing Using FnCpf1 and LbCpf1 Nucleases at Redefined and Altered PAM Sites. Mol. Plant 2018, 11, 999-1002. [CrossRef]

98. Wang, M.; Mao, Y.; Lu, Y.; Tao, X.; Zhu, J. Multiplex Gene Editing in Rice Using the CRISPR-Cpf1 System. Mol. Plant 2017, 10, 1011-1013. [CrossRef] [PubMed]

99. Anzalone, A.V.; Koblan, L.W.; Liu, D.R. Genome editing with CRISPR-Cas nucleases, base editors, transposases and prime editors. Nat. Biotechnol. 2020, 38, 824-844. [CrossRef] [PubMed] 
100. Hua, K.; Tao, X.; Han, P.; Wang, R.; Zhu, J.-K. Genome Engineering in Rice Using Cas9 Variants that Recognize NG PAM Sequences. Mol. Plant 2019, 12, 1003-1014. [CrossRef] [PubMed]

101. Monsur, M.B.; Shao, G.; Lv, Y.; Ahmad, S.; Wei, X.; Hu, P.; Tang, S. Base Editing: The Ever Expanding Clustered Regularly Interspaced Short Palindromic Repeats (CRISPR) Tool Kit for Precise Genome Editing in Plants. Genes (Basel) 2020, 11, 466. [CrossRef]

102. Hua, K.; Tao, X.; Zhu, J.-K. Expanding the base editing scope in rice by using Cas9 variants. Plant Biotechnol. J. 2019, 17, 499-504. [CrossRef]

103. Zong, Y.; Wang, Y.; Li, C.; Zhang, R.; Chen, K.; Ran, Y.; Qiu, J.-L.; Wang, D.; Gao, C. Precise base editing in rice, wheat and maize with a Cas9-cytidine deaminase fusion. Nat. Biotechnol. 2017, 35, 438-440. [CrossRef]

104. Lu, Y.; Zhu, J.-K. Precise Editing of a Target Base in the Rice Genome Using a Modified CRISPR/Cas9 System. Mol. Plant 2017, 10, 523-525. [CrossRef]

105. Li, J.; Sun, Y.; Du, J.; Zhao, Y.; Xia, L. Generation of Targeted Point Mutations in Rice by a Modified CRISPR/Cas9 System. Mol. Plant 2017, 10, 526-529. [CrossRef]

106. Xu, Y.; Lin, Q.; Li, X.; Wang, F.; Chen, Z.; Wang, J.; Li, W.; Fan, F.; Tao, Y.; Jiang, Y.; et al. Fine-tuning the amylose content of rice by precise base editing of the Wx gene. Plant Biotechnol. J. 2021, 19, 11-13. [CrossRef] [PubMed]

107. Kuang, Y.; Li, S.; Ren, B.; Yan, F.; Spetz, C.; Li, X.; Zhou, X.; Zhou, H. Base-Editing-Mediated Artificial Evolution of OsALS1 In Planta to Develop Novel Herbicide-Tolerant Rice Germplasms. Mol. Plant 2020, 13, 565-572. [CrossRef]

108. Zhang, R.; Chen, S.; Meng, X.; Chai, Z.; Wang, D.; Yuan, Y.; Chen, K.; Jiang, L.; Li, J.; Gao, C. Generating broad-spectrum tolerance to ALS-inhibiting herbicides in rice by base editing. Sci. China Life Sci. 2020. [CrossRef]

109. Liu, X.; Qin, R.; Li, J.; Liao, S.; Shan, T.; Xu, R.; Wu, D.; Wei, P. A CRISPR-Cas9-mediated domain-specific base-editing screen enables functional assessment of ACCase variants in rice. Plant Biotechnol. J. 2020, 18, 1845-1847. [CrossRef] [PubMed]

110. Ahmad, S.; Shahzad, R.; Jamil, S.; Tabassum, J.; Chaudhary, M.A.M.; Atif, R.M.; Iqbal, M.M.; Monsur, M.B.; Lv, Y.; Sheng, Z.; et al. Regulatory aspects, risk assessment, and toxicity associated with RNAi and CRISPR methods. In CRISPR and RNAi Systems; Elsevier: Amsterdam, The Netherlands, 2021; pp. 687-721.

111. Podevin, N.; Davies, H.V.; Hartung, F.; Nogué, F.; Casacuberta, J.M. Site-directed nucleases: A paradigm shift in predictable, knowledge-based plant breeding. Trends Biotechnol. 2013, 31, 375-383. [CrossRef] [PubMed]

112. Lema, M.A. Regulatory aspects of gene editing in Argentina. Transgenic Res. 2019, 28, 147-150. [CrossRef]

113. Gao, W.; Xu, W.-T.; Huang, K.-L.; Guo, M.; Luo, Y.-B. Risk analysis for genome editing-derived food safety in China. Food Control 2018, 84, 128-137. [CrossRef]

114. Normile, D. Gene-edited foods are safe, Japanese panel concludes. Science 2019. [CrossRef]

115. Thygesen, P. Clarifying the regulation of genome editing in Australia: Situation for genetically modified organisms. Transgenic Res. 2019, 28, 151-159. [CrossRef]

116. Yan, F.; Kuang, Y.; Ren, B.; Wang, J.; Zhang, D.; Lin, H.; Yang, B.; Zhou, X.; Zhou, H. Highly Efficient A.T to G.C Base Editing by Cas9n-Guided tRNA Adenosine Deaminase in Rice. Mol. Plant 2018, 11, 631-634. [CrossRef]

117. Hahn, F.; Nekrasov, V. CRISPR/Cas precision: Do we need to worry about off-targeting in plants? Plant Cell Rep. 2019, 38, 437-441. [CrossRef] [PubMed]

118. Jin, S.; Zong, Y.; Gao, Q.; Zhu, Z.; Wang, Y.; Qin, P.; Liang, C.; Wang, D.; Qiu, J.-L.; Zhang, F.; et al. Cytosine, but not adenine, base editors induce genome-wide off-target mutations in rice. Science 2019, eaaw7166. [CrossRef] [PubMed]

119. Koo, T.; Lee, J.; Kim, J.-S. Measuring and Reducing Off-Target Activities of Programmable Nucleases Including CRISPR-Cas9. Mol. Cells 2015, 38, 475-481. [CrossRef] [PubMed]

120. Wienert, B.; Wyman, S.K.; Richardson, C.D.; Yeh, C.D.; Akcakaya, P.; Porritt, M.J.; Morlock, M.; Vu, J.T.; Kazane, K.R.; Watry, H.L.; et al. Unbiased detection of CRISPR off-targets in vivo using DISCOVER-Seq. Science 2019, 364, 286-289. [CrossRef]

121. Slaymaker, I.M.; Gao, L.; Zetsche, B.; Scott, D.A.; Yan, W.X.; Zhang, F. Rationally engineered Cas9 nucleases with improved specificity. Science 2016, 351, 84-88. [CrossRef]

122. Kleinstiver, B.P.; Pattanayak, V.; Prew, M.S.; Tsai, S.Q.; Nguyen, N.T.; Zheng, Z.; Joung, J.K. High-fidelity CRISPR-Cas9 nucleases with no detectable genome-wide off-target effects. Nature 2016, 529, 490-495. [CrossRef]

123. Chen, J.S.; Dagdas, Y.S.; Kleinstiver, B.P.; Welch, M.M.; Sousa, A.A.; Harrington, L.B.; Sternberg, S.H.; Joung, J.K.; Yildiz, A.; Doudna, J.A. Enhanced proofreading governs CRISPR-Cas9 targeting accuracy. Nature 2017, 550, 407-410. [CrossRef]

124. Lee, J.K.; Jeong, E.; Lee, J.; Jung, M.; Shin, E.; Kim, Y.; Lee, K.; Jung, I.; Kim, D.; Kim, S.; et al. Directed evolution of CRISPR-Cas9 to increase its specificity. Nat. Commun. 2018, 9, 3048. [CrossRef]

125. Mehta, D.; Stürchler, A.; Anjanappa, R.B.; Zaidi, S.S.-A.; Hirsch-Hoffmann, M.; Gruissem, W.; Vanderschuren, H. Linking CRISPR-Cas9 interference in cassava to the evolution of editing-resistant geminiviruses. Genome Biol. 2019, 20, 80. [CrossRef]

126. Aman, R.; Ali, Z.; Butt, H.; Mahas, A.; Aljedaani, F.; Khan, M.Z.; Ding, S.; Mahfouz, M. RNA virus interference via CRISPR/Cas13a system in plants. Genome Biol. 2018, 19, 1. [CrossRef]

127. Gentzel, I.N.; Park, C.H.; Bellizzi, M.; Xiao, G.; Gadhave, K.R.; Murphree, C.; Yang, Q.; LaMantia, J.; Redinbaugh, M.G.; Balint-Kurti, P.; et al. A CRISPR/dCas9 toolkit for functional analysis of maize genes. Plant Methods 2020, 16, 133. [CrossRef] [PubMed]

128. Fan, T.; Yang, W.; Zeng, X.; Xu, X.; Xu, Y.; Fan, X.; Luo, M.; Tian, C.; Xia, K.; Zhang, M. A Rice Autophagy Gene OsATG8b Is Involved in Nitrogen Remobilization and Control of Grain Quality. Front. Plant Sci. 2020, 11. [CrossRef] [PubMed] 
129. Shang, F.; Chao, X.; Meng, K.; Meng, X.; Li, Q.; Chen, L.; Wang, J. Fine Mapping of a Grain Shape Gene from a Rice Landrace Longliheinuo-Dwarf (Oryza sativa L. ssp. japonica). Agronomy 2020, 10, 380. [CrossRef]

130. Zhang, A.; Gao, Y.; Li, Y.; Ruan, B.; Yang, S.; Liu, C.; Zhang, B.; Jiang, H.; Fang, G.; Ding, S.; et al. Genetic Analysis for Cooking and Eating Quality of Super Rice and Fine Mapping of a Novel Locus qGC10 for Gel Consistency. Front. Plant Sci. $2020,11$. [CrossRef]

131. Khahani, B.; Tavakol, E.; Shariati, V.; Rossini, L. Meta-QTL and ortho-MQTL analyses identified genomic regions controlling rice yield, yield-related traits and root architecture under water deficit conditions. Sci. Rep. 2021, 11, 6942. [CrossRef] [PubMed]

132. Islam, M.; Ontoy, J.; Subudhi, P. Meta-Analysis of Quantitative Trait Loci Associated with Seedling-Stage Salt Tolerance in Rice (Oryza sativa L.). Plants 2019, 8, 33. [CrossRef]

133. Raza, Q.; Riaz, A.; Bashir, K.; Sabar, M. Reproductive tissues-specific meta-QTLs and candidate genes for development of heat-tolerant rice cultivars. Plant Mol. Biol. 2020, 104, 97-112. [CrossRef] [PubMed] 